\title{
LEGISLATIVE INTENT AND PUBLIC CHOICE
}

\section{Daniel A. Farber* and Philip P. Frickey**}

TMAGINE a country where laws are usually the unpredictable results of shifting coalitions and arbitrary agendas. Legislative committees produce official reports that purport to explain those laws, but are actually concocted by staff members and lobbyists to deceive courts about the meaning of the statutes. After statutes are passed, legislators contrive to smuggle their personal interpretations of the laws into later committee reports and debates dealing with other matters. Courts foolishly give credence to this deceptive evidence of a legislative intent that itself is little more than a legal fiction; moreover, the courts sometimes even elevate counterfeit legislative history above the duly enacted language of the law itself. Only by jettisoning the whole idea of legislative intent can judges escape this chamber of illusions.

This scenario is only a slight caricature of how legislative intent is viewed by several prominent judges appointed by President Reagan. Although no one judge would agree that everything in our opening paragraph is true, it is an accurate synthesis of their collective writings. These judges, including most notably Justice Antonin Scalia, have advocated a radical reassessment of the concept of legislative intent. They would reject, or at least sharply limit, reliance on legislative history, and they would abandon any consideration of congressional actions or statements after a statute was passed. Justice Scalia, joined to some extent by Judge Frank Easterbrook, would go further and jettison the whole idea of legislative intent as a guide to interpretation. ${ }^{1}$

* Henry J. Fletcher Professor of Law, University of Minnesota; Visiting Professor, Stanford Law School.

** Associate Professor of Law, University of Minnesota. We thank William Eskridge, Morris Fiorina, Ronald Levin, Jonathan Macey, and the participants at the law and economics workshop of Stanford University for helpful comments on an earlier draft of this Article.

2 Qualms about legislative history or the meaningfulness of the concept of legislative intent are not new; what is new is the intensity of the current judicial attack. Perhaps it is not entirely a coincidence tbat these judges do not share the political views of the Congresses 
The ultimate issue raised by these judges is the extent to which legislation reflects a coherent congressional view of the public interest. The same issue has also received intense scholarly attention by a highly influential group of economists and political scientists. These public choice theorists apply economic methodology to the study of political institutions. Some aspects of the public choice hterature support the specific concerns raised by Justice Scalia and his fellow judges. More generally, the judges' skepticism toward the integrity of legislatures finds a deep resonance in the public choice literature. ${ }^{2}$ That scholarship suggests that congressional enactments are not motivated by conceptions of the public interest; ratlier, federal statutes inight reflect private interest deals, re-election posturing, or arbitrary outcoines. As such, perhaps judges should accord statutes only formal, not functional, supremacy to judge-made law and private ordering. Under this return to Blackstonian jurisprudence, judges would enforce tlie statute only witlin the domain of the plain meaning of its words and abandon interpretation based on the legal fictions of legislative intent and statutory purposes.

We believe, however, that public choice theory is compatible with a more respectful attitude toward legislative intent. In our view, public clioice theory is consistent with a flexible, pragmatic approacl to statutory construction, in which legislative intent plays an important role.

In this Article, we suggest how public choice actually supports this pragmatic approach. In Part I, we consider the attacks on the possibility of legislative colierence that are based on Arrow's Theorem $^{3}$ and related work. As we slow, the most recent models in this area tend to support more traditional ideas of legislative coher-

that enacted most of our statutes. In any event, the new attack has reopened the debate about legislative intent and given it a new tenor.

${ }^{2}$ Recently, we extensively surveyed the public choice literature. See Farber \& Frickey, The Jurisprudence of Public Choice, 65 Tex. L. Rev. 873 (1987); Farber \& Frickey, Integrating Public Choice and Public Law: A Reply to Lee and DeBow, 66 Tex. L. Rev. (forthcoming April 1988); Lee \& DeBow, Understanding (and Misunderstanding) Public Choice: A Response to Farber and Frickey, 66 Tex. L. Rev. (forthcoming April 1988). For another useful discussion of the public choice literature, see Macey, Promoting Public-Regarding Legislation Through Statutory Interpretation: An Interest Group Model, 86 Colum. L. Rev. 223 (1986).

${ }^{3}$ See infra text accompanying notes 8-16. 
ence. Thus, we argue, the notion of a coherent legislative intent is consistent with current public choice theory.

In Part II, we consider the integrity of the documentary record used to help determine intent by focusing on Justice Scalia's concerns about the judicial use of legislative history in interpreting statutes. Here, public choice theory is relevant but less central, and we consider a variety of empirical and anecdotal evidence. Our conclusion is that Justice Scalia's cynicism on this score is excessive.

In Part III, we consider and reject Justice Scalia's argument that legislative intent should be considered irrelevant even when it can be determined. We then present a simple model of statutory interpretation using elementary decision theory. This model treats judges as rational decisionmakers who attempt to decipher legislative messages under conditions of uncertainty. Decision theory indicates that rational choice involves consideration of both the probability that a given interpretation is correct and the consequences of adopting that interpretation. The model suggests that statutory interpretation, like other judicial inquiries, is an exercise in practical reason rather than foundationalist formalism. One conclusion derived from the model is that subsequent legislative history should not be entirely rejected, as Justice Scalia and others have argued. Although such legislative history ordinarily says hittle about the original legislative intent surrounding the adoption of the statute, it does have some limited use in evaluating the consequences of adopting a particular interpretation.

\section{The Problem of Legislative Coherence}

A particularly intriguing branch of public choice scholarship discusses the incoherence of majority voting. ${ }^{4}$ Some of this scholarship is highly pessimistic about the viability of majority rule, in legislatures or elsewhere. ${ }^{\sigma}$ In particular, this literature suggests that "political processes are fundamentally chaotic and unpredict-

- In some of this discussion, we borrow from Farber \& Frickey, supra note 2, at 901-06.

${ }^{3}$ See W. Riker, Liberalism Against Populism 1-2, 65-66, 112-13, 200, 236 (1982); Cass, Looking with One Eye Closed: The Twilight of Administrative Law, 1986 Duke L.J. 238, 245 ("democratic choice model faces serious impediments best captured by Professor Kenneth Arrow's impossibility theorem"). Similar problems exist with regard to administrative decisionmaking. See Hammond \& Miller, A Social Choice Perspective on Expertise and Authority in Bureaucracy, 29 Am. J. Pol. Sci. 1 (1985). 
able, that almost anything can happen."” Thus, as Judge Richard Posner has recently pointed out, pubhic choice theory has made statutory interpretation highly problematic by undermining the traditional notion of a coherent legislative purpose. ${ }^{7}$

The heart of the matter is "Arrow's Paradox." In some circumstances, majority voting leads to "cyching majorities" that cannot choose among three or more mutually exclusive alternatives. ${ }^{\circ} \mathrm{Ken}$ neth Arrow proved that, in general, no method of voting ${ }^{10}$ or any other method of making social decisions can avoid the possibility

- Panning, Formal Models of Legislative Processes, in Handbook of Legislative Research 680 (G. Loewenberg, S. Patterson \& M. Jewell eds. 1985) (citing Schofield, Formal Political Theory, 14 Quality \& Quantity 249, 249-50, 272 (1980)). For the intriguing argument that this political flux promotes the overall stability of a pluralist political system, see Miller, Pluralism and Social Choice, 77 Am. Pol. Sci. Rev. 734, 744 (1983).

${ }^{7}$ As Judge Posner recently explained:

Since Hart and Sacks wrote, a. large number of factors have combined to inflict a mortal blow on the comfortable view of statutory interpretation they espoused. Chief among these factors have been the breakdown of political consensus; the growth of social choice theory on the foundation of Arrow's impossibility theorem; the rediscovery of interest groups by economists and political scientists on both the left and the right; the criticisms of the "public-interestedness" of legislation by the conservative and deregulation movements; the debunking of the "canons of statutory construction"; and the attacks made by Continental philosophers and their American followers on the objectivity of interpretation.

Posner, The Decline of Law as an Autonomous Discipline: 1962-1987, 100 Harv. L. Rev. 761, 774 (1987) (citing H. Hart \& A. Sacks, The Legal Process: Basic Problems in the Making and Application of Law (tent. ed. 1958)). In the next sentence, Judge Posner speaks of the "inherently problematic character of statutory interpretation." Id. Note that Judge Posner's list of contributing factors is dominated by those relating to the public choice movement: Arrow's Theorem, interest group theory, and the rejection of the public interest theory of legislation. See also Eskridge \& Frickey, Legislation Scholarship and Pedagogy in the PostLegal Process Era, 48 U. Pitt. L. Rev. 691, 691-710 (1987) (explaining the Hart and Sacks legal-process synthesis and its vulnerability in light of public choice scholarship).

${ }^{8}$ See K. Arrow, Social Choice and Individual Values (2d ed. 1963). A particularly good sketch of the proof is given in J. Bonner, Introduction to the Theory of Social Choice 63-71 (1986). The paradox is also closely associated with D. Black, The Theory of Committees and Elections (1958). The paradox actually was discovered in the late 18th century by the Marquis de Condorcet. See D. Mueller, Public Choice 39 (1979).

- Here is a simple example of cycling majorities. Three children-Alice, Bobby, and Cindy-have been pestering their parents for a pet. The parents agree that the children may vote to have a dog, a parrot, or a cat. Suppose the children's orders of preferences are as follows: Alice-dog, parrot, cat; Bobby-parrot, cat, dog; Cindy-cat, dog, parrot. In this situation, majority voting cannot pick a pet. A majority (Alice and Cindy) will vote for a dog rather than a parrot; a majority (Alice and Bobby) will vote for a parrot rather than a cat; and a majority (Bobby and Cindy) will vote for a cat rather than a dog.

10 For an exceptionally clear discussion of alternative voting methods, see W. Riker, supra note 5 , at $67-111$. 
of such paradoxical results. ${ }^{11}$ Where cycling is present, therefore, maneuvers such as agenda manipulation or "strategic voting" may become decisive. Numerous studies about voting in legislatures have focused on strategic behavior, such as logrolling, ${ }^{12}$ that can substantially affect legislative outcomes. ${ }^{13}$

The likelihood of cycling depends on the number of voters, the number of issues, and the distribution of preferences. ${ }^{14} \mathrm{~A}$ wellknown theorem, sometimes called the "chaos result," suggests that given a large number of voters and issues and fairly reasonable assumptions about preferences, cycling is almost inevitable and will include every possible outcome..$^{15}$ Under these circumstances, someone who controls the agenda can lead the legislature by the nose to any desired result. ${ }^{16}$

Concern about cycling and strategic behavior has led to great skepticism about the meaningfulness of legislative choice. Among political scientists, the most notable skeptic is Professor William

${ }^{11}$ See id. at 116-19. For several examples of the occurrence of the paradox in the legislative setting, see Riker, The Paradox of Voting and Congressional Rules for Voting on Amendments, 52 Ain. Pol. Sci. Rev. 349, 352-62 (1958).

${ }^{12}$ Logrolling is the trading of votes on one issue for desired votes on other issues. It usually occurs in situations where individual votes represent a significant percentage of the total electorate and where compliance with trading arrangements can be observed easily. See Tullock, Problems of Majority Voting, 67 J. Pol. Econ. 571, 571 (1959).

${ }^{13}$ For example, in the "pet picking" example, supra note 9 , we assumed that each child would vote sincerely. But one child with perfect information can prevent the cycle and substantially satisfy her own desires by strategic voting. Assume that Alice, who likes parrots almost as much as dogs but who hates cats, has discovered the preferences of her siblings. If the first pairwise contest is dog versus parrot, sincere voting on her part will eventually lead to the selection of a cat. (A dog will win the first round of voting with votes from Alice and Cindy, but a cat will be the final preference because Bobby and Cindy will prefer a cat in the second round of voting between a dog and a cat.) If instead Alice casts a strategic vote for a parrot rather than a dog in the initial selection, a parrot will be the ultimate winner, and she will avoid the most distasteful outcome from her perspective.

For an overview of the studies of strategic legislative behavior, see Panning, supra note 6 , at 676-80. Some interesting recent work suggests that "majority voting procedures with endogenous agendas generally produce 'essentially unique' outcomes." Baron \& Ferejolın, Bargaining and Agenda Formation in Legislatures, Am. Econ. Rev., May 1987, at 303 (Papers and Proceedings of the 99th Annual Meeting of the American Economic Association).

14 Some authors suggest that in reality cycles are likely to be rare, at least unless someone has a sufficient incentive to contrive a cycle. See W. Riker, supra note 5, at 121-23, 128; Koehler, Ordinal Preference Games: An Analysis of Legislative Coalition Formation Without Transferable Utility, 78 Am. Pol. Sci. Rev. 750, 762 (1984) (most United States Senate votes involve three or fewer issues, making cycling either unhkely or impossible).

${ }^{15}$ See W. Riker, supra note 5 , at 186-88.

18 See id. at 169-95. 
Riker. He argues that voting is so susceptible to cycling and strategic behavior that outcomes cannot be understood as expressing the voters' values. Hence, "the meaning of social choices is quite obscure": choices may reflect the voters' true values, successful strategic behavior, or the "accidental amalgamation of what the manipulators (perhaps unintentionally) happened to produce."17 In Riker's view, outcomes bear no particular relationship to the voters' views of public pohicy. Indeed, he believes that under the chaos theorem, any tiny change in the situation can lead to wildly different outcomes. ${ }^{18}$

Riker's conclusions suggest, for example, that when a legislator proposes a clarifying amendment to eliminate an ambiguity in statutory language, a statute bearing no resemblance to the one originally passed may ultimately be enacted. Under such circumstances, it is perhaps meaningless to ask which interpretation of a statute Congress would have adopted if the question had arisen. If the question of how to interpret the current provision had arisen, Congress might well have adopted something completely different. In any event, because in Riker's view the actual results reveal little about the legislators' underlying preferences, we have no basis for deciding how they would answer any question not actually before them.

Professor Riker's view of the meaninglessness of legislative outcomes has been echoed by Judge Easterbrook:

Because legislatures comprise many members, they do not have "intents" or "designs," hidden yet discoverable. Each member may or may not have a design. The body as a whole, however, has only outcomes. It is not only impossible to reason from one statute to another but also impossible to reason from one or more sections of a statute to a problem not resolved.

This follows from the discoveries of public choice theory. Although legislators have individual lists of desires, priorities, and preferences, it turns out to be difficult, sometimes impossible, to aggregate these lists into a coherent collective choice. Every system of voting has flaws. The one used by legislatures is particularly dependent on the order in which decisions are made. . . . It is fairly

17 See id. at 167.

18 See id. at 192. For a case study in which agenda control apparently did influence a legislative outcome greatly, see W. Eskridge \& P. Frickey, Cases and Materials on Legislation: Statutes and the Creation of Public Policy 369-77 (1987). 
easy to show that someone with control of the agenda can manipulate the choice so that the legislature adopts proposals that only a minority support. The existence of agenda control makes it impossible for a court-even one that knows each legislator's complete table of preferences-to say what the whole body would have done with a proposal it did not consider in fact. ${ }^{19}$

Judge Easterbrook concludes that although "the order of decisions and logrolling are not total bars to judicial understanding," nevertheless "they are so integral to the legislative process that judicial predictions of how the legislature would have decided issues it did not in fact decide are bound to be little more than wild guesses."20

The heart of the Easterbrook-Riker position is Arrow's Theorem, for it is cycling that most often creates the opportunities for strategic behavior and renders legislative outcomes suspect. Arrow's Theorem, despite its importance, may not have as much to say about legislative behavior as Judge Easterbrook and Professor Riker seem to beheve. As one scholar recently observed, "the theoretical results achieved by the formal analysis of legislative choice are markedly inconsistent with our empirical knowledge of legislatures such as the U.S. Congress." ${ }^{21} \mathrm{He}$ explained:

As formal theorists themselves have increasingly recognized, social choice theory as it pertains to legislative voting is unsatisfactory in ways that are not easily dismissed. The immediate focus of dissatisfaction is the radical inconsistency between what the theory im-

19 Easterbrook, Statutes' Domains, 50 U. Chi. L. Rev. 533, 547-48 (1983) (citations omitted).

${ }^{20}$ Id. at 548. Judge Posner, though concerned about the implications of public choice theory, is less inclined than Judge Easterbrook to take these implications to their logical extreme:

Public-choice theory makes the attribution of unified purpose to a collective body increasingly difficult to accept-though I think it is possible to overdo one's skepticism in this regard. Institutions act purposively, therefore they have purposes. A document can manifest a single purpose even though those who drafted and approved it had a variety of private motives and expectations.

Posner, Legal Formalism, Legal Realism, and the Interpretation of Statutes and the Constitution, 37 Case W. Res. L. Rev. 179, 195-96 (1986-87).

Judge Easterbrook, too, has sometimes drawn back from the full implications of his position. See Easterbrook, Ways of Criticizing the Court, 95 Harv. L. Rev. 802, 828 n.57 (1982) (although "the 'drafters,' as a group, may have no consistent intent," nevertheless the "written product . . . may have a structure that governs questions of interpretation"). Note, however, that this somewhat restrained statement predates the more pronounced skepticism expressed in Easterbrook, supra note 19.

${ }^{21}$ Panning, supra note 6, at 689 . 
plies and wliat is in fact observed. . . . Unless tlie observed stability of legislative processes is simply dismissed as illusory, this inconsistency between theory and observation poses awkward problems for formal theorists. ${ }^{22}$

The reasons for the gap between theory and reality are not entirely clear, but recent scholarship identifies several major factors.

To begin with, the assumptions underlying Arrow's Theorem are not always applicable. ${ }^{23}$ For example, Arrow's result does not hold if the members of the group have uni-peaked preferences. In a legislature, this would occur if each legislator ranked his choices on a liberal-to-conservative scale and differed only in his preferred location on the scale. ${ }^{24}$ The hikelihood of having sufficiently "well-behaved" preferences to avoid Arrow's Theorem is presumably much greater in a small group such as a legislative committee. Nevertheless, according to a recent paper, roll call data reveal that from 1919 to 1984, the preferences of members of the United States Congress have fallen largely on a unidimensional, liberal-conservative spectrum. ${ }^{25}$

22 Id. at 680-81; see also Shepsle, Prospects for Formal Models of Legislatures, 10 Legis. Stud. Q. 5, 10 (1985) ("neither interpretation" of the chaos theorem--that either there must be a dictatorial agenda setter or legislative outcomes must "wander anywhere"-_"rings true in any real-world legislative context").

${ }^{23}$ For recent summaries of the various methods of evading Arrow's result, see Farber, From Plastic Trees to Arrow's Theorem, 1986 U. Ill. L. Rev. 337, 353-54; Sen, Social Choice and Justice: A Review Article, $23 \mathrm{~J}$. Econ. Literature 1764, 1770-74 (1985).

Another intriguing escape from Arrow's Theorem is discussed in M. Shubik, A GameTheoretic Approach to Political Economy 613-15 (1984). Arrow's Theorem does not hold if we assume that voters gamble on how candidates will behave in office, so that an election is essentially a lottery involving packages of programs. Id. If individual voters have well-behaved preferences over the set of all lottery outcomes, a utility function can be constructed for the entire group, thus avoiding Arrow's result. (One of Arrow's assumptions is that the set of alternatives is finite, but allowing lotteries with various odds makes the set of possible choices infinite.)

${ }^{24}$ See A. Sen, Collective Choice and Social Welfare 166-72 (1970).

${ }^{26}$ See K. Poole \& H. Rosenthal, The Unidimensional Congress, 1919-1984 (1986) (unpublished paper) (copy on file with the Virginia Law Review Association). Poole and Rosenthal suggest that this strong unidimensionality in roll call voting is attributable in part to earlier bargaining at the committee level and to optimizing behavior by political actors who have only incomplete information.

Unidimensionality "solves" the following problems: (1) it allows horse-trading to occur among spatially adjacent actors in defining the midpoint on a given issue. Conditional on the midpoint, liberals and conservatives will look like they are voting in a consistent, nonstrategic fashion that maintains their voting histories . . . thereby preserving their reputations . . . with their electorates; (2) from the viewpoint of vot- 
Another method of preventing cycling is to impose structural restrictions, such as agenda rules, on voting procedures; thus, one important focus of public choice theory concerns agenda setting, decisional structure, and arbitrary outcomes. ${ }^{26}$ Legislatures apparently use a variety of structures, rules, and norms to ameliorate the problem of cycling majorities. ${ }^{27}$ As a result, legislatures possess a "structure-induced equilibrium," to use the phrase coined by social scientists researcling the impact of Arrow's Theorem in concrete legislative settings. ${ }^{28}$ Althougl Judge Easterbrook acknowledges the importance of agendas in legislatures, lie seems to view them as an additional source of arbitrariness and unpredictability. ${ }^{29} \mathrm{On}$ the contrary, the recent public clioice literature suggests that agenda rules make outcomes more predictable and therefore more understandable. Moreover, agenda rules increase the power of tlie legislative leadership to control outcomes, at least in the sliort run. Having powerful leadership should increase tle predictability and intelligibility of results. ${ }^{30}$

ers and campaign contributors, a single index greatly simplifies decision problems in an information poor environment; similarly, the dimension greatly facilitates cue-taking by members of Congress, who, massive staffs notwithstanding, are clearly information overloaded when faced with hundreds of roll calls a year.

Id. at 28 (footnote and citations omitted).

${ }^{28}$ For an overview of the literature, see Panning, supra note 6, at 676-78, 681-82. Agenda control and legislative decisional structure can also influence outcomes even when cycling majorities are not present; for example, structural restrictions can keep popular alternatives entirely off the voting agenda. See generally Levine \& Plott, Agenda Influence and Its Implications, 63 Va. L. Rev. 561, 564 (1977) ("agenda or groupings in which alternatives are considered for adoption or elimination can be a major parameter in determining what a group will ultimately choose"). For some experimental confirmation of this hypothesis, see Wilson, Forward and Backward Agenda Procedures: Committee Experiments on Structurally Induced Equilibrium, 48 J. Pol. 390 (1986).

${ }^{27}$ These devices and norms have other consequences as well, such as their tendency to increase legislative bias in favor of the status quo. For a discussion of how the constitutional structure of decisionmaking delineated in article I prevents cycling and favors the status quo, see Mayton, The Possibilities of Collective Choice: Arrow's Theorem, Article I, and the Delegation of Legislative Power to Administrative Agencies, 1986 Duke L.J. 948, 953-58.

${ }^{28}$ See Shepsle \& Weingast, Structure-Induced Equilibrium and Legislative Choice, 37 Pub. Choice 503, 515 (1981); see also Shepsle \& Weingast, Uncovered Sets and Sophisticated Voting Outcomes with Implications for Agenda Institutions, $28 \mathrm{Am}$. J. Pol. Sci. 49, 69 (1984) (concluding that "only in the simplest of institutions . . . does the cyclicity of the majority-rule preference relation directly characterize outcomes"); Shepsle \& Weingast, When Do Rules of Procedure Matter?, 46 J. Pol. 206, 208 (1984) (considering the effect of institutional practices on majority coalitions).

${ }^{20}$ See Easterbrook, supra note 19, at 547-48.

so Riker may be correct that democratic procedures place a premium on the creativity 
Various institutional features of a legislature may promote stability and coherence. Even without these institutional features or deviations from the assumptions underlying Arrow's Theorem, instability in voting outcomes may not be a substantial problem. In carefully controlled voting experiments, political scientists have found that voting outcomes are fairly predictable and clustered even when the voters' preferences lead to massive cycles. Theoretically, the results of voting should wander over all possible outcomes, but in reality voting has a strong tendency to favor balanced compromise outcomes. ${ }^{31}$

These empirical results are paralleled by new, more sophisticated formal models. ${ }^{32}$ In these formal models, voting outcomes remain stable and predictable-even when the preference scheme is saturated with cycles. ${ }^{33}$ These models involve a wide range of assumptions, ranging from strategic voting and open agenda processes $^{34}$ to a partially random amendment process involving coalitions of voters. ${ }^{35}$ The models also use various mathematical tools to describe the focal area of legislative outcomes, variously defined as the "uncovered set," the "yolk," or the "strong point."

and intelligence of leaders, but we doubt that many people share his view that this is somehow objectionable. See W. Riker, supra note 5 , at 200 .

31 See Ferejohn, Fiorina \& Weisberg, Toward a Theory of Legislative Decision, in Game Theory and Political Science 170-74 (P. Ordeshook ed. 1978); Fiorina \& Plott, Committee Decisions Under Majority Rule: An Experimental Study, 72 Am. Pol. Sci. Rev. 575, 590 (1978). On the other hand, even where there is a single alternative that dominates all others, it is not always picked. See Hoffman \& Packel, A Stochastic Model of Committee Voting with Exogenous Costs: Theory and Experiments, 27 Behavioral Sci. 43, 44-45 (1982). (Note, by the way, how some of the participants cleverly evaded the experimental design to find a "mutually acceptable" solution. Id. at 52-53.)

${ }^{32}$ For a brief summary of the literature, noting its relevance to the Riker thesis, see Coleman \& Ferejohn, Democracy and Social Choice, 97 Ethics 6, 23-24 (1986).

${ }^{33}$ See Ferejohn, McKelvey \& Packel, Limiting Distributions for Continuous State Markov Voting Models, 1 Soc. Cboice \& Welfare 45 (1984); Grofman, Owen, Noviello \& Glazer, Stability and Centrality of Legislative Choice in the Spatial Context, $81 \mathrm{Am}$. Pol. Sci. Rev. 539 (1987); Miller, A New Solution Set for Tournaments and Majority Voting: Further Graph-Theoretical Approaches to the Tbeory of Voting, 24 Am. J. Pol. Sci. 68 (1980).

${ }^{34}$ See McKelvey, Covering, Dominance, and Institution-Free Properties of Social Choice, 30 Am. J. Pol. Sci. 283, 285-87 (1986); Shepsle \& Weingast, Uncovered Sets and Sophisticated Voting Outcomes with Implications for Agenda Institutions, 28 Am. J. Pol. Sci. 49, 6971 (1984) (exploring the effects of different agenda formation rules).

${ }^{35}$ See Ferejohn, McKelvey \& Packel, supra note 33, at 58-59; see also Banks, Sophisticated Voting Outcomes and Agenda Control, 1 Soc. Choice \& Welfare 295 (1985) (similar results with exogenous agenda). 
We will not attempt to discuss these highly technical mathematical models in any detail, but the reader is at least entitled to some idea of what these terms mean. Briefly, the uncovered set consists of outcomes that could survive sophisticated voting procedures by "dominating" other outcomes. ${ }^{36}$ The yolk is the smallest sphere that intersects all of the median planes, where a median plane is one that divides the voters' ideal points (each voter's most preferred outcome) into groups of equal size. In a rough sense, the center of the yolk is the median of the various voters' ideal outcomes. ${ }^{37}$ The strong point is the one that beats the most alternatives in pairwise voting. ${ }^{38}$

Remarkably, these very different definitions all turn out to describe very similar outcomes. ${ }^{39}$ These solutions also have the property of becoming more and more specific, as the voting game comes closer to having a single majority outcome that can beat every other outcome. ${ }^{40}$ Thus, small changes in preferences or agendas do not lead to big outcome swings; these models limit voting outcomes to relatively small subsets of all possible outcomes. Even in the presence of considerable cycling possibilities, the models predict stability of a kind missing from earlier models. ${ }^{41}$

Another source of stability consists of behavioral norms such as fairness. ${ }^{42}$ Consider a very simple voting situation in which $A, B$,

${ }^{36}$ See McKelvey, supra note 34, at 288-89, 296-97. Equivalently, we can define the uncovered set as consisting of those alternatives that can defeat all other alternatives in no more than two moves (either they defeat any alternative $X$, or they can defeat some alternative $Y$ that in turn can beat $X$ ). See id. at 289 . To see what this has to do with sophisticated agenda voting, the reader may find it helpful to work through the following hypothetical. Suppose $A$ beats $B$ and $C, B$ beats $C, C$ beats $D$, and $D$ beats $A$ and $B . B$ is not part of the uncovered set, because it neither beats $A$ directly nor heats anything else tbat can beat $A$. (Note, however, that $B$ does cycle with $A$, but tbe cycle goes through both $C$ and $D$ before getting to $A$.) A little fiddling with pencil and paper will show that if voters are sophisticated, $B$ cannot win, regardless of the agenda order. On the final vote, voters will vote for $B$ only if it is paired with $C$, but because they prefer $A$ to both choices, they will always pick it when it appears earlier on the agenda.

${ }^{37}$ See Ferejohn, McKelvey \& Packel, supra note 33 , at 59.

${ }^{38}$ See Grofman, Owen, Noviello \& Glazer, supra note 33, at 541 .

39 For development of this point and a summary of the prior literature, see id. at 547-49; see also McKelvey, supra note 34, at 304-05 (uncovered set centers around yolk).

to See Cox, The Uncovered Set and the Core, 31 Am. J. Pol. Sci. 408, 417-20 (1987) (uncovered set shrinks to the core).

\$1 For a general description of the results, see Panning, supra note 6, at 681 .

42 Indeed, one common problem in designing voting experiments is the risk that participants will vote for "fair" rather than individually rational outcomes. See Fiorina \& Plott, 
and $C$ must vote over how to divide $\$ 1000$ among them. ${ }^{43}$ Assuming $A, B$, and $C$ seek to maximize their own gains in this distributive situation, any proposal can always be upset by another proposal preferred by two of the players. For example, if $A$ and $B$ vote to divide the money equally between themselves, $C$ can make a motion to give $A$ two-thirds and to keep one-third. This makes $A$ and $C$ both better off, so the amendment wins. But then $B$ can offer $C$ a 50-50 split, making $B$ and $C$ both better off. This process has no ending point; in technical terms, this game has no "core." there is a natural solution point: an equal three-way split (technically, the "value solution" of the game ${ }^{45}$ ). In addition to its equitable appeal, this solution is a sort of equilibrium. It is true that any player could offer an amendment that would beat this outcome-but what would be the point of doing so and thereby setting off a round of endless cycling? In a sense, the existence of massive cycling provides the basis for a new form of equilibrium adopted precisely to avoid the cycles. ${ }^{46}$

Such norms should emerge even more strongly in voting situations that already have a certain stability, such as those with institutionally induced equilibria or reasonably small uncovered sets. The incentive to move away from these "natural" equilibria is

supra note 31, at 583 (describing pilot experiments); Wilson, Results on the Condorcet Winner: A Committee Experiment on Time Constraints, 17 Simulation \& Games 217, 222-25 (1986).

${ }^{43}$ As we will see, this simple model captures the essence of the "chaos" results on majority voting:

One common interpretation . . . is that institutions that use majority rule ought not to work: since choices are cyclical, losers should always be able to find some alternative they like better that could defeat the present status quos, and so on ad infinitum. Thus, all legislatures should be in constant turmoil as losers try to reverse decisions they do not like.

Grofman, Owen, Noviello \& Glazer, supra note 33, at 539. The simple voting game in the text has the same attribute, inasmuch as a loser can always propose a new split that will win a majority over any status quo. For a general discussion of such "fair division" games, see M. Shubik, Game Theory in the Social Sciences: Concepts and Solutions 306-11 (1982).

"See Wiley, Antitrust and Core Theory, 54 U. Chi. L. Rev. 556, 558-61 (1987).

${ }^{45}$ See M. Shubik, Game Theory, supra note 43, at 183-84; see also id. at 179-80, 413 (noting relevance of value solution to fair division games). In our example, this solution would he economically efficient if the players are risk averse, value alternative uses of their time (other than playing the game), or have other transaction costs associated with making proposals and voting.

46 One hope of game theorists is that the "solutions" to games will provide a deeper understanding of social norms and institutions, rather than simply identifying clever strategies for individual players. See id. at 2-3, 7 . 
small because the ensuing cycling is likely to send the outcome back into the equilibrium area anyway. Rational behavior calls for quickly finding and sticking with the equilibrium area. We can assume that successful institutions will have such norms, thus reinforcing any tendency toward equilibrium that is already present. The norms need not, of course, be explicit, but may be based on implicit understandings and sanctions, which are especially likely to arise in situations such as legislatures, where participants have long-term, ongoing interactions. ${ }^{47}$

Indeed, "natural selection" would eliminate any legislature that failed to develop defenses to cycling and instability. What purpose is served by a legislature the outcomes of which are entirely unpredictable and fortuitous? One might as well have legislation chosen at random from lists of proposals. Obviously, a totally unstable legislature cannot further any version of the public good, nor can it reliably advance the welfare of any interest group. Furthermore, it cannot even further the self-interest of the legislators themselves: if the outcome of the legislative process is fortuitous, no one has any incentive to reward individual legislators.

In short, we have very strong reasons, both empirical and theoretical, for believing that actual legislatures do not suffer from the instability and incoherence some public choice theories have predicted. Consequently, the Easterbrook-Riker view of the "meaninglessness" of legislative outcomes should not lead judges to abandon a search for legislative intent when interpreting a statute.

Apart from this negative conclusion, can we draw any positive implications regarding statutory interpretation from this segment of the public choice literature? We believe that at least some tentative conclusions can be drawn from this evolving body of theory. We stress the need for tentativeness for several reasons: first, because of the inherent difficulties of applying tidy formal models to

${ }^{17}$ See Koehler, The P-Set: A Structure-Induced Equilibrium for Sequential Legislative Voting, 31 Am. J. Pol. Sci. 940, 962 (1987) ("Legislators are expected to constrain their preferences for outcomes in order to achieve a preferred process, one which is stable."). For discussions of how such implicit understandings can arise in long-term interactions, even when the parties are entirely self-interested and no external enforcement of agreements is possible, see R. Axelrod, The Evolution of Cooperation 73-105 (1984); R. Scott, Conflict and Cooperation in Long Term Contracts 25-36 (University of Virginia Working Paper Series No. 7,1987 ). For an example of such cooperative behavior in an actual legislative setting, see Krehbiel, Unanimous Consent Agreements: Going Along in the Senate, 48 J. Pol. 541 (1986). 
an untidy legal world; second, because the models are themselves still evolving; and third, because of the risk that lay people such as law professors will misinterpret technical mathematical models. Mindful of all these caveats, however, we do think public choice theory has some useful guidance to offer.

Let us begin with the easy case of uni-peaked preferences. Suppose that the legislative history clearly indicates that the close vote on a crucial provision was on ideological grounds, so that all legislators "left" of a certain point voted one way and those to the "right" voted another. Some empirical evidence suggests that this situation is not at all uncommon. ${ }^{48}$ If the application of the provision to a given situation is ambiguous, the information about voting preferences may be helpful in deciding what intention to impute to the legislature. Public choice theory suggests that the legislation represents the outcome most preferred by the median legislator..$^{48}$ Given two possible interpretations of the provision, one may seem much closer than the other to this median position. A court can then say with some assurance that if the two interpretations had been offered for a vote, the one closer to the median legislator's views would have won. ${ }^{\text {so }}$

Actual legislative situations may be messier because outcomes deviate from uni-peakedness or because preferences fall on more than one dimension. ${ }^{51}$ The recent theories discussed above suggest, however, that an analogue to the "median legislator" still exists. The "sense of the legislature" or the legislative center of gravity corresponds to the solution sets (yolk, strong point, or uncovered set) of recent formal models, and all of these solutions tend to be close together. ${ }^{52}$ Some of the models explicitly combine the views of all legislators but give less weight to those with extreme preferences, thereby resembling in that respect the median of a one-dimensional distribution. ${ }^{53}$ Given the preferences of legislators, these

48 See supra note 25 and accompanying text.

48 See W. Riker, supra note 5 , at 62-63.

${ }^{50}$ The idea that courts attempt to identify the position of the median legislator is suggested in Fiorina, Legislator Uncertainty, Legislative Control, and the Delegation of Legislative Power, 2 J. Law, Econ. \& Org. 33, 39-40 (1986).

s1 Also, the precise preferences may he hard to determine, so as a practical matter we must replace the median voter with a fuzzier concept of legislative consensus.

${ }^{B 2}$ See supra text accompanying notes $32-41$.

${ }^{53}$ See Grofman, Owen, Noviello \& Glazer, supra note 33 , at 541-43, 548-49. 
theories suggest that we can identify a centrist position that represents the likely outcome of legislation. Having done so, we can ask which interpretation of a provision is closer to the centrist legislative position. We can think of this interpretation as either representing the views of a "typical" centrist legislator, or we can think of it as delineating the target the legislature was trying to hit-either way, we can identify which outcomes are closest to the centrist position. Thus, we can generalize the concept of a "median legislator" to a much broader range of conditions.

We do not suggest that courts perform the elaborate calculations involved in these mathematical models. We believe that many judges will, however, have a good intuitive sense of the legislative center of gravity. ${ }^{54}$ Given some understanding of the location of the legislative center, a judge will often be able to discern that one reading of a provision places it much closer to the legislative center than another. As we suggest in Part III, statutory interpretation is a complex process, not necessarily limited to considerations of original intent. When original intent is relevant, however, finding the legislature's pohtical center may be a very useful way to think about intent. In any event, there is no reason to give way to the cynicism about legislative stability and coherence expressed by Professor Riker and Judge Easterbrook.

\section{Legislative INTENT aNd Legislative HistoRy}

One time-honored source of legislative intent is the legislative history of the statute. ${ }^{55}$ Recently, however, Justice Scalia has roundly attacked the current judicial practice of routinely considering legislative history. He has asserted that even if legislative intent is a coherent concept, legislative history provides an exceedingly poor documentary record of it. This assault upon the use of legislative history in statutory interpretation is premised on the notion that legislative history is the product of legislators at their worst-promoting private interest deals, strategically posturing to mislead judges, or abdicating all responsibility to their unelected

\footnotetext{
st After all, the subjects of voting experiments were ignorant of game theory, but their actions showed they were nevertheless able to identify a centrist solution; thus, judges may also be able to discern stable centrist outcomes without knowing the mathematics of uncovered sets.

ss See, e.g., W. Eskridge \& P. Frickey, supra note 18, at 709-60.
} 
staffs (who presumably either have their own political agendas or randomly run amok). The relationship between this vision of the legislative process and the assumptions of public choice theory is obvious.

Justice Scalia's attack began when he sat on the United States Court of Appeals for the District of Columbia Circuit. In Hirschey v. Federal Energy Regulatory Commission, ${ }^{\text {s6 }}$ then-Judge Scalia discussed a House committee report concerning amendments to a federal statute. ${ }^{57}$ The report noted a split in the courts of appeals concerning the interpretation of certain statutory language unaffected by the amendments and stated that the approach taken by the Ninth Circuit was incorrect. Judge Scalia was unimpressed:

It is most interesting that the House Committee rejected the interpretation of the Ninth Circuit, and perhaps that datum should be accorded the weight of an equivalently unreasoned law review article. But the authoritative, as opposed to the persuasive, weight of the Report depends entirely upon how reasonable it is to assume that the rejection was reflected in the law which Congress adopted. I frankly doubt that it is ever reasonable to assume that the details, as opposed to the broad outlines of purpose, set forth in a committee report come to the attention of, much less are approved by, the house which enacts the committee's bill. And I think it time for courts to become concerned about the fact that routine deference to the detail of committee reports, and the predictable expansion in that detail which routine deference has produced, are converting a system of judicial construction into a system of committee-staff prescription. ${ }^{\mathbf{5 8}}$

At first glance, much of this language seems unexceptional. It seems reasonable, for example, to assume with Judge Scalia that minutia in committee reports are not considered carefully by legislators, particularly those not on the committee. A reluctance to accord significant weight to such minutia, particularly if they seem irrelevant to or inconsistent with the general purposes of the statute, also seems reasonable. In addition, Judge Scalia's criticisms of judicial overreliance on committee reports may in at least one respect be oddly understated, in that he seemingly assumes that

sB 777 F.2d I (D.C. Cir. 1985).

${ }^{87}$ H.R. Rep. No. 120, 99th Cong., 1st Sess. 17, reprinted in 1985 U.S. Code Cong. \& Admin. News 132, 145.

s8 Hirschey, 777 F.2d at 7-8 (Scalia, J., concurring) (footnote omitted) (emphasis added). 
committee reports are sometimes properly authoritative, rather than simply one of many sources informing statutory meaning.

Upon closer inspection, however, Judge Scalia's dictum in Hirschey contains some extraordinary elements. The last sentence quoted above refers to "a system of committee-staff prescription." This is a rather stark judicial impeachment of the legislative process-Judge Scalia is, in effect, asserting that legislators have abdicated important responsibilities to staff members, who routinely connive to subvert the judicial function by planting their (not even their legislators') subjective desires about statutory meaning into committee reports, hoping that their ideas will blossom later in judicial opinions. To support these assertions, Judge Scalia attached a footnote to the excerpt quoted above presenting an anecdote from the Senate floor. ${ }^{5 \theta}$

From the footnote it would appear that Senator Robert Dole, the committee chair who was managing floor consideration of a tax bill, admitted under sharp fire from Senator William Armstrong that he had not even read the entire committee report, much less written any of it, that the report was prepared wholly by staff, and that senators, including committee meinbers, had little opportunity to object to the report's contents. ${ }^{60}$ It turns out, however, that

so See id. at 7 n.1.

so The footnote, in its entirety, read as follows:

Several years ago, the following illuminating exchange occurred between members of the Senate, in the course of floor debate on a tax bill:

Mr. ARMSTRONG. ... My question, which may take [the chairman of the Committee on Finance] by surprise, is this: Is it the intention of the chairman that the Internal Revenue Service and the Tax Court and other courts take guidance as to the intention of Congress from the committee report which accompanies this bill?

Mr. DOLE. I would certainly hope so . . . .

Mr. ARMSTRONG. Mr. President, will the Senator tell me whether or not he wrote the committee report?

Mr. DOLE. Did I write the committee report?

Mr. ARMSTRONG. Yes.

Mr. DOLE. No; the Senator from Kansas did not write the committee report.

Mr. ARMSTRONG. Did any Senator write the committee report?

Mr. DOLE. I have to check.

Mr. ARMSTRONG. Does the Senator know of any Senator who wrote the committee report?

Mr. DOLE. I might be able to identify one, but I would have to search. I was here all during the time it was written, I might say, and worked carefully with the staff as they worked. ...

Mr. ARMSTRONG. Mr. President, has the Senator from Kansas, the chairman 
in context the exchange between Armstrong and Dole was more benign than Judge Scalia's presentation might suggest. Indeed, what Judge Scalia seemingly characterized as a gross malfunction of the legislative process was in reality an admirable performance-in Senator Armstrong's own evaluation. ${ }^{61}$ The Armstrong-

of the Finance Committee, read the committee report in its entirety?

Mr. DOLE. I am working on it. It is not a bestseller, but I am working on it.

Mr. ARMSTRONG. Mr. President, did members of the Finance Committee vote on the committee report?

Mr. DOLE. No.

Mr. ARMSTRONG. Mr. President, the reason I raise the issue is not perhaps apparent on the surface, and let me just state it: . . . The report itself is not considered by the Committee on Finance. It was not subject to amendment by the Committee on Finance. It is not subject to amendment now by the Senate.

...

... If there were matter within this report which was disagreed to by the Senator from Colorado or even by a majority of all Senators, there would be no way for us to change the report. I could not offer an amendment tonight to amend the committee report.

... [F] or any jurist, administrator, bureaucrat, tax practitioner, or others who might chance upon the written record of this proceeding, let me just make the point that this is not the law, it was not voted on, it is not subject to amendment, and we should discipline ourselves to the task of expressing congressional intent in the statute.

Id. (citing 128 Cong. Rec. S8659 (daily ed. July 19, 1982)).

${ }^{61}$ One might assume, based on the excerpt from the Congressional Record, see supra note 60, that Senator Armstrong considered specific language in the committee report to be inconsistent with the language of the bill, that he believed that committee staff had run amok in preparing the report, that he felt powerless to make an effective objection, and that he more generally found Dole's work as chairman slovenly. In fact, the context was quite different. Just prior to the colloquy quoted by Judge Scalia, Armstrong made a number of statements to the contrary. First, he noted that he was a member of the Finance Committee and supported the bill in the form it was reported, although he did plan to propose some amendments concerning aspects of the bill that he found "distasteful." 128 Cong. Rec. 16914-15 (1982). As a member of the committee, presumably he had good access to coinmittee staff, as well as the responsibility to rein them in if they acted improperly. Second, and also just prior to the language quoted by Judge Scalia, Armstrong heaped praise upon Dole's work as committee chairman. See id. at 16918 (In getting a majority of the committee to agree to the bill within a necessarily short time frame, Dole showed "a degree of legislative perspicacity, management, and statesmanship that is rare. In fact, in my experience and observation it has never been excelled.").

Based on what Judge Scalia presented, one might also think that this was a simple bill and that staff wrote into the report matter that could easily have been inserted in the bill. In fact, the bill was a huge and highly complicated piece of tax legislation that ran seventy pages in the Congressional Record! Perhaps no senator had read the entire committee report-but how many likely read the entire bill?

Next, one might examine what Judge Scalia deleted internally in the quotation used in his footnote. First, after stating "I would certainly hope so" to Armstrong's question about 


\section{Dole colloquy demonstrates that staffs prepare committee reports,}

whether the committee report should guide interpretation of the statute, Dole continued: "plus not only the committee report but hopefully in the debate on certain compliance provisions tbat we will probably have lengthy discussions on the next few days." Id. This language suggests that Dole, Armstrong, and everyone else understood that senators had other methods of creating somewhat authoritative legislative history or of decreasing the authoritativeness of a committee report.

Second, after reporting that he had "worked carefully with the staff as they worked" on the report, Dole continued: "As I recall, during the July 4 recess week there were about five different working groups of staff from both parties, the joint committee, and the Treasury working on different provisions." Id. Needless to say, these remarks rebut the appearance-created by Judge Scalia's editing, not by Armstrong's remarks-that low-level, irresponsible staff prepared the report in a setting hostile to the representation and consideration of different points of view.

Finally, following Armstrong's comment that the report "is not subject to amendment now by the Senate," Armstrong clearly stated why he made tbese remarks. Id. We reproduce his statement, putting the portions not included by Judge Scalia in italics:

I became aware recently of the practice which I think honestly is a most injudicious practice in which some courts have in fact relied upon committee report language as if it were a statute.

I only wish the record to reflect that this is not statutory language. It is not before us. If there were matter within this report which was disagreed to by the Senator from Colorado or even by a majority of all Senators, there would be no way for us to change the report. I could not offer an amendment tonight to amend the committee report.

I only wish to put that in the RECORD. I am not leaning in any particular direction. It is not my purpose at this moment to remonstrate about any particular language in the committee report. But for any jurist, administrator, bureaucrat, tax practitioner, or others who might chance upon the written record of this proceeding, let me just make the point that this is not the law, it was not voted on, it is not subject to amendment, and we should discipline ourselves to the task of expressing congressional intent in the statute.

Having made that point I do not wish to belabor it, but I might just add this footnote: I expect to make the same point with respect to other committee reports as they come down the pike and at some stage I may implement a scheme which I have long had in mind which is to offer language to a bill-I do not intend to do it on this particular bill-to simply endorse or reject specifically the language of committee reports.

What I find is that so often these committee reports are treated not only as if they were a statute, but as if they were something better than statutes, as if they somehow superseded statutory enactment and particularly in the case of tax law I think that is a very dangerous practice.

So on this quiet and otherwise uneventful evening, I thought I would make that point.

Id. at 16918-19.

After some further remarks by Armstrong that are not relevant here, Dole responded:

I can only say so far as the committee report, everything that was said in tbe Senate Finance Committee is recorded. In fact, I listened to some of the recordings trying to figure out what we really meant myself. So we had that information along with the documents provided at the time and statements made by members who were offering 
that legislators do not formally ratify language in reports, and that at least one senator-Armstrong-hoped courts in the interpretive exercise would not treat language in reports on a par with, or more important than, statutory language. ${ }^{62}$ The colloquy provides no support, however, for Judge Scalia's assertion about "committeestaff prescription" of judicial functions.

Judge Scalia also presented an analysis of the unrehability of legislative history in a speech he delivered soon after Hirschey. ${ }^{63}$ In the speech, he took an even more extreme approach, suggesting that if he were writing on a clean slate he might hold all legislative history inadmissible for purposes of statutory interpretation. In the alternative, he indicated that some actions and statements on the legislative floor should take precedence over committee reports. ${ }^{64} \mathrm{He}$ asserted that the primary purpose for committee re-

amendments. So we tried to base the report on information that was solid. That does not mean there may not be cases where there were some misunderstandings of interpretation, which the Senator from Kansas indicated earlier was the reason in the principal area today that we modified one of the safe-harbor leasing provisions because the distinguished Senator from Minnesota had a very different recollection of what we did than the Senator from Kansas had, and the record was not clear.

So I would only say if, in fact, someone has taken literary license, that is one thing.

But we hope the report is based on fact and on what did occur at the time. Id. at 16919 .

Thus, Senator Armstrong was expressing a general concern about courts using committee reports as if they were statutes-or "something better than statutes"-which is a legitimate concern. See infra text accompanying notes 100-04. This exchange cannot properly be viewed as a case study of actual committee report abuse.

${ }^{62}$ See also K. Kofmehl, Professional Staffs of Congress 121-23 (1st ed. 1962) (noting that committee reports were staff product and that members of Congress occasionally complained about their lack of opportunity to review reports).

${ }^{63}$ Address by Judge Antonin Scalia, Speech on Use of Legislative History [hereinafter Scalia Speech] (delivered between fall 1985 and spring 1986 at various law schools in varying forms) (copy on file with the Virginia Law Review Association).

o4 Judge Scalia stated:

As an intermediate federal judge, I can hardly ignore legislative history when I know it will be used by the Supreme Court. But it seems to me we can at least be more selective in the sorts of legislative history we employ-requiring some indication that it at least genuinely reflects the intent of one of the houses of Congress. For that purpose, I suppose I would rank most highly legislative history consistuig of amendments defeated on the floor-where it seems clear that the reason for the defeat was rejection of a particular course now said to be contained in the unamended text. I suppose next to that would be extended floor debate-at least in circumstances, which occasionally occur, where the final text is actually being crafted on the floor.

At the bottom of the list I would place-what hitherto seems to have been placed at the top: the committee report.

Id. at 18. 
ports currently was to influence judicial interpretation. ${ }^{65}$ As in Hirschey, Judge Scalia's only empirical support for the unreliability and manufactured nature of legislative history was the ArmstrongDole colloquy. ${ }^{66}$

Justice Scalia's views on legislative history have received mixed reactions. During his confirmation hearing for the Supreme Court, Senator Charles Grassley criticized the Hirschey footnote, ${ }^{67}$ and Senator Paul Simon seemed dubious, ${ }^{68}$ whereas Senator Howell Heflin seemed somewhat supportive. ${ }^{69}$ Several other Reagan appointees to the federal appellate bench have been more enthusiastic. Judges James Buckley ${ }^{70}$ and Kenneth Starr ${ }^{71}$ have sounded some general support, and Judge Alex Kozinski has embraced Justice Scalia's viewpoint with particular enthusiasm. ${ }^{72}$ Moreover,

65 Judge Scalia specifically suggested the following about the purpose of committee reports:

Ironically but understandably enough, the more the courts have relied upon committee reports in recent years, the less reliable they have become. In earlier days, when their sole purpose was to inform the members of Congress who were to vote upon the committee's bill, it was not as absurd (thougb still absurd enough) to pretend that those members had read and agreed with the report. But nowadays, when it is universally known and expected that judges will resort to the reports as authoritative expressions of "legislative intent" on the details they address, affecting the courts rather than informing the Congress has become the primary purpose of the exercise. In all of their ever-increasing, profuse detail, it is less that the courts refer to them because they exist, than that they exist because the courts refer to them.

Id. at 7. See infra note 79 and accompanying text for refutation of the empirical assumption made by Judge Scalia in this passage.

68 See Scalia Speech, supra note 63, at 5-7.

${ }^{67}$ See Nomination of Judge Antonin Scalia, to be Associate Justice of the Supreme Court of the United States: Hearings Before the Senate Comm. on the Judiciary, 99th Cong., 2d Sess. 65-68 (1986) [hereinafter Hearings on Scalia Nomination].

${ }^{68}$ See id. at 105-06.

${ }^{69}$ See id. at 74-75; cf. id. at 106-07 (remarks of Senator Mathias suggesting that, at least as a matter of congressional committee practice, more attention sbould be paid to committee report language).

${ }^{70}$ See International Bhd. of Elec. Workers v. NLRB, 814 F.2d 697, 715-20 (D.C. Cir. 1987) (Buckley, J., concurring).

${ }^{71}$ See Natural Resources Defense Council v. Environmental Protection Agency, 822 F.2d 104, 113 (D.C. Cir. 1987); Federal Election Comm'n v. Rose, 806 F.2d 1081, 1090 (D.C. Cir. 1986); International Bhd. of Teamsters v. Interstate Commerce Comm'n, 801 F.2d 1423, 1428 n.4 (D.C. Cir. 1986), reh'g granted and review denied, 818 F.2d 87 (D.C. Cir. 1987). In American Civil Liberties Union v. Federal Communications Comm'n, 823 F.2d 1554 (D.C. Cir. 1987), Judge Starr stated that "[w]e in the judiciary have become shamelessly profligate and unthinking in our use of legislative history." Id. at 1583 (Starr, J., dissenting in part).

${ }^{72}$ Judge Kozinski's concurrence in Wallace v. Christensen, 802 F.2d 1539 (9th Cir. 1986), illustrated his support: 
Justice Scalia himself, now on the Supreme Court, has expressed continued allegiance. ${ }^{73}$

A realistic appreciation of the legislative process does raise doubts about how reliably legislative history represents legislative intentions, even assuming that those "unenacted" intentions are useful for interpretation. Much legislative history, in context, may be what Charles Curtis called "the ashcans of the legislative process," ${ }^{\prime 4}$ bits and fragments of thought (or the lack thereof) that cannot fairly be regarded as saying anything reliable about the meaning to be accorded the statute. As Judge Scalia suggested in Hirschey, the legislative body as a whole is unlikely to pay much attention to the minutia found in legislative history. ${ }^{75}$ Moreover, a committee report may contain material that simply lacked the political force to make its way into the statute..$^{76}$ Perhaps even more

The fact of the matter is that legislative history can be cited to support almost any proposition, and frequently is. The propensity of judges to look past the statutory language is well known to legislators. It creates strong incentives for manipulating legislative history to achieve through the courts results not achievable during the enactment process. The potential for abuse is great. Judge (now Justice) Scalia has persuasively warned against relying on detailed discussions in legislative reports [quotation from Hirschey omitted]. A footnote to this passage vividly demonstrates the danger of according legislative reports controlling weight: Reports are usually written by staff or lobbyists, not legislators; few if any legislators read the reports; they are not voted on by the committee whose views they supposedly represent, much less by the full Senate or House of Representatives; they cannot be amended or modified on the floor by legislators who may disagree with the views expressed therein. Committee reports that contradict statutory language or purport to exphicate the meaning or applicability of particular statutory provisions can short-circuit the legislative process, leading to results never approved by Congress or the President. Of course, all this goes doubly for floor statements by individual legislators.

Id. at 1559-60 (Kozinski, J., concurring in the judgment) (footnote omitted). For instances in which federal judges appointed by other Presidents have remarked favorably upon at least some of the elements of Judge Scalia's approach in Hirschey, see Riddle v. Secretary of Health \& Human Servs., 817 F.2d 1238, 1247-48 (6th Cir. 1987) (Engel, J., dissenting); International Bhd. of Elec. Workers v. NLRB, 814 F.2d 697, 712-13 (D.C. Cir. 1987); Abourezk v. Reagan, 785 F.2d 1043, 1054-55 n.11 (D.C. Cir. 1986), aff'd by equally divided Court, 108 S. Ct. 257 (1987).

${ }^{73}$ See Immigration \& Naturalization Serv. v. Cardoza-Fonseca, 107 S. Ct. 1207, 1224 (1987) (Scalia, J., concurring in the judgment).

74 C. Curtis, It's Your Law 52 (1954).

${ }^{75}$ See Hirschey, 777 F.2d at 8 (Scalia, J., concurring).

${ }^{76}$ See Lane, Legislative Process and Its Judicial Renderings: A Study in Contrast, $48 \mathrm{U}$. Pitt. L. Rev. 639, 659 (1987) (quoting speech by Judge Abner Mikva); see also Mikva, Reading and Writing Statutes, 48 U. Pitt. L. Rev. 627, 631 (1987) (explaining purposes committee reports serve other than explaining the text of the statute). Karl Llewellyn once remarked, "I think any aspect of legislative history may be useful, and should be looked at, for what it 
worrisome is that judicial interpretation of a statute will be skewed by legislative history planted just for that purpose.77

Several things seem to distinguish the Scalia-led attack upon the use of legislative history from its forbears. First, Justice Scalia and his followers indulge in some doubtful factual assumptions. For example, Judge Kozinski's assertion that "few if any legislators read the reports"78 is mere unsupported assertion, if it is not flatly incorrect. To the contrary, according to a principal study of congressional policymaking procedures, legislators outside the committee and their staffs focus primarily on the report, not the bill itself. ${ }^{79}$ The important factor is whether the public officials have abdicated their decisionmaking responsibilities to staff. When Justice Scalia's own example of committee-report abuse is placed in proper context, ${ }^{80}$ it does not support his fear of "committee-staff prescription." ${ }^{\text {N1 }}$ No doubt there are instances in which congressional staff exceed their appropriate role; ${ }^{82}$ however, what their role should be

is worth; thus, the contrived 'friendly colloquy' deserves attention, frequently, as evidence of what was carefully left out of the bill." K. Llewellyn, The Common Law Tradition: Deciding Appeals 529 (1960).

${ }^{77}$ See Wasby, Legislative Materials as an Aid to Statutory Interpretation: A Caveat, $12 \mathrm{~J}$. Pub. L. 262, 267-68 (1963). Notwithstanding Senator Armstrong's comments, supra note 61, many members of Congress are probably well aware of the judicial use of legislative history for purposes of statutory interpretation. See, e.g., K. Kofmehl, Professional Staffs of Congress 119 (3d ed. 1977); Moorhead, A Congressman Looks at the Planned Colloquy and Its Effect in the Interpretation of Statutes, 45 A.B.A.J. 1314 (1959).

${ }^{78}$ See supra note 72 .

72 This reliance is described as follows:

Reports are directed primarily at members of tbe House and Senate and seek to persuade the membership to endorse the committee's recommendations when it comes up for a vote on the floor. For some members, or their staff aides, the report is the only document they read before deciding how to vote on an issue. The report, therefore, is the principal official means of communicating a committee decision to the entire chamber.

W. Oleszek, Congressional Procedures and the Policy Process 94 (2d ed. 1984) (footnote omitted). Oleszek noted that reports also provide guidance to courts and administrative agencies later called upon to interpret the statute. See id. at $97 \mathrm{n} .32$.

Similarly, Eric Redman, a former Senate aide, observed that committee reports provide information to courts and the Executive about legislative intent and then stated that "[w]ithin the Senate itself, reports are important chiefly because many Senators read nothing else before deciding how to vote on a particular bill. A good report, therefore, does more than explain-it also persuades." E. Redman, The Dance of Legislation 140 (1973).

Bo See supra note 61 .

82 Hirschey, 777 F.2d at 8 (Scalia, J., concurring).

82 See generally M. Malbin, Unelected Representatives: Congressional Staff and tbe Future of Representative Government (1980) (discussing tension between democratic theory 
is surely the primary concern of the legislative rather than the judicial branch. In short, Justice Scalia and others have not established the universal truth of legislator abuse of legislative history or of congressional staff overreaching, have not given the legal community any effective way of identifying either in particular instances, and have not demonstrated any reason why change in judicial use of legislative history would "reform" congressional processes.

In American public law, the traditional response to criticisms about the reliability of legislative history has sounded largely in confession and avoidance-that is, agreement that legislative history is not some simple transcription of legislative intent, but faith that courts can, and should, sort the wheat from the chaff. For example, Henry Hart developed a thoughtful "tentative restatement of the law" of legislative history usage that suggests that courts carefully evaluate the contextual relevance, competence, and probative value of legislative history. ${ }^{83}$ In a nutshell, this approach indicates that the internal legislative history of the statute that was officially before the legislature at the time of enactment may be considered, but that the probative value of the legislative history depends on the extent to which it generally illuminates the overall purposes of the statute. ${ }^{84}$ Thus, "[e]vidence in the internal legislative history of a statute concerning a specific application en-

and reality of large staff role). For an overview of political science studies about legislative staff, see Hammond, Legislative Staffs, in Handbook of Legislative Research, supra note 6, at 273-319.

${ }^{83}$ See H. Hart \& A. Sacks, The Legal Process $1284-86$ (tent. ed. 1958). These materials indicate that "one of the editors" developed the tentative restatement, id. at 1284; it has been attributed to Hart. See F. Newman \& S. Surrey, Legislation-Cases and Materials 66971 (1955).

${ }^{84}$ See H. Hart \& A. Sacks, supra note 83 , at $1284-86$. This is consistent with the general approach to statutory interpretation adopted in the Hart \& Sacks materials, under which the interpreter attributes an organizing purpose to the statute. See id. at 1410-17 (summary of their approach); cf. Martin v. Commissioner of Internal Revenue, 783 F.2d 81 (7th Cir. 1986), in which Judge Posner wrote:

As for the general danger that a committee report might not reflect the understanding of a majority of the members of Congress-might, indeed, not even be known to them, Hirschey v. FERC, 777 F.2d 1, 7-8 (D.C. Cir. 1985) [(Scalia, J., concurring)]-it is enough to say that we do not rest our decision entirely on the legislative history, nor use it to reach a result inconsistent with the language of the statute and with the purpose that can be inferred from that language without recourse to legislative history.

Id. at 83; cf. Eskridge \& Frickey, supra note 7, at 694-700 (discussion of Hart \& Sacks). 
visaged by individual legislators should be given weight only to the extent that the application envisaged fits rationally with other indicia of general purpose." "should go a long way to take care of the manipulation problem."

Somewhat similarly, Henry Friendly, in his sympathetic overview of Felix Frankfurter's approach to statutory interpretation, stated that

if an intent clearly expressed in committee reports is within the permissible limits of the [statutory] language and no construction manifestly more reasonable suggests itself, a court does pretty well to read the statute to mean what the few legislators liaving the greatest concern with it [i.e., the committee] said it meant to them. ${ }^{87}$

Friendly, too, thought courts capable of identifying categories of probative legislative history and suggested that courts go slowly in interfering with the conduct of committees and legislative sponsors. ${ }^{88}$ More recently, Judge Richard Posner noted that it is "tempting to argue," as has Justice Scalia, "that because legislators vote on the statutory language rather than on the legislative history, they cannot be presumed to have assented to all that has been said, either in the committee reports or on the floor, about a bill that becomes law." 89 Yet he also has rejected this argument and counseled prudent consideration of legislative history. ${ }^{90}$

${ }^{85}$ H. Hart \& A. Sacks, supra note 83 , at $1285-86$.

${ }^{86}$ Id. at 1286.

${ }^{87}$ H. Friendly, Mr. Justice Frankfurter and the Reading of Statutes, in Benchmarks 216 (1967).

${ }^{88}$ Friendly cautioned courts:

There is, of course, the fear that the "intention" expressed even in committee reports and sponsors' statements may have been manufactured-perhaps, indeed, placed there for the very reason that it was known that the language could not be placed in the act itself. But is it not going too far to ask the courts to police sucb abdication of legislative responsibility?

This problem is quite different from the smuggling of "intention" into hearing materials, which the legislators cannot prevent. The Justice [Frankfurter] protested against undue reliance on such materials . . . .

Id. at 216 n.114 (discussing Shapiro v. United States, 335 U.S. 1, 48-49 (1948) (Frankfurter, J., dissenting)).

${ }^{89}$ R. Posner, The Federal Courts: Crisis and Reform 269 (1985).

$\therefore$ See id. at 269-70. Following the quotation in the text accompanying note 89, Judge Posner continued:

But if legislators know that courts look to legislative history in interpreting statutes-and they do know this-then when they vote for a bill they are assenting, in a 
In short, American public law has quite properly recognized that statutory meaning is necessarily greatly influenced by statutory context. ${ }^{91}$ Legislative history is part of that context, and some aspects of it-such as committee reports-will frequently represent the most intelligent exposition available of what the statute is all about. Legislative history is, after all, merely evidence of intent. That it may not be perfectly reliable evidence is no reason to exclude it from consideration entirely. Indeed, even if legislative history were systemically biased, that would not justify ignoring it, because a decisionmaker can always compensate for known bias in assessing evidence. Of course, it would be a mistake to give potentially unreliable or biased evidence determinative weight. Nevertheless, unless the costs of obtaining evidence are much higher than its relevance or unless the decisionmaker cannot be trusted to assess its value, potentially useful evidence should not be excluded from consideration. Thus, although legislative history should not be the starting point nor the end of the interpretive process, it is a legitimate part of it.

We find nothing in the new attack led by Justice Scalia to justify jettisoning this traditional approach. As suggested above, when stripped of its overbroad generalizations and intensity, the attack seems to collapse into older arguments against the use of legislative history that have never prevailed in the American legal interpretive community. Moreover, to the extent that the technical findings of public choice theory-rather than simply the rejection

sense, to at least some of what is in that history. Moreover, the emphasis that the argument places on assent may be misplaced . . . . [S]ince an unknown fraction of all bills represent "deals" struck with or between interest groups, it is not necessarily true that each member of the legislative majority behind a particular bill will have bothered to study the details of the bill he voted for; he may simply have assented to the deal struck by the sponsors of the bill. And unless the terms of the deal are stated accurately in the committee reports and in the floor comments of the sponsors, the sponsors will have difficulty striking deals in the future.

This picture is especially persuasive if we assume, as we should, that there is " $\log$ rolling"- that is, vote trading-in the legislative process. Log rolling imphes that legislators often vote against their personal convictions. This makes it unrealistic to deem that each legislator assents only to those aspects of statutory meaning that are fixed unambiguously in the language of the bill, interpreted without reference to the sponsors' intentions as reflected in their statements in the committee reports and on the floor.

Id. at 269.

92 See H. Hart \& A. Sacks, supra note 83, at 1148-79, 1415. 
of the public-interest theory of legislation generally-have anything to say regarding Justice Scalia's suggestions, they probably cut against him. Political science has long stressed the overarching influence of legislative committees on legislative outcomes. ${ }^{92}$ Traditionally, committee power was attributed to the committee's roles as legislative "gatekeeper" and "pohcy incubator," to its expertise and agenda control, and to reciprocal deference among committees. ${ }^{93}$ Recently, public choice scholarship has suggested that a critical element explaming the demonstrable committee power in Congress is the frequent existence of an ex post committee veto.94 Briefly, even if the standing committee's proposal is modified on the floor of the legislature, the committee will later have great influence on the final outcome if (1) a conference committee on the bill is necessary (because it did not pass both houses of Congress in identical form), and (2) the standing committee essentially populates and controls the conference committee. Both of these contingencies occur for nearly all major bills in Congress. ${ }^{95}$ The presence of an ex post veto strengthens the committee's ex ante gatekeeping and proposal powers (for example, it makes little sense to use a discharge petition to dislodge a bill from committee if the members of that committee are likely to control the conference committee down the road).

Although this recent public choice scholarship suggests little in particular about committee reports, ${ }^{96}$ it does indicate that the

${ }^{92}$ For an overview of the political science literature, see Eulau \& McCluggage, Standing Committees in Legislatures, in Handhook of Legislative Research, supra note 6, at 395-470.

ss See Shepsle \& Weingast, The Institutional Foundations of Committee Power, $81 \mathrm{Am}$. Pol. Sci. Rev. 85, 85 (1987).

or See id.

95 See id. at 94-95. For criticism and defense of this analysis, see Why Are Congressional Committees Powerful?, 81 Am. Pol. Sci. Rev. 929-45 (1987) (criticism by Keith Krehbiel and response by Kenneth Shepsle and Barry Weingast).

is Morris Fiorina has suggested that congressional committees may sometimes constitute "handfuls of unrepresentative members," and that courts "when reconstructing legislative intent . . . may rely too heavily on the committee reports" prepared by such members and their staffs. Fiorina, Legislator Uncertainty, Legislative Control, and the Delegation of Legislative Power, 2 J.L. Econ. \& Org. 33, 49 \& n.22 (1986); see also Eskridge, Politics Without Romance: Implications of Public Choice Theory for Statutory Interpretation, 74 Va. L. Rev. 283-95 (1988) (problem of cycling majorities is not that "anything can happen," but that what does happen may be the result of agenda control and committee bias). In part, Fiorina's suggestion apparently assumes that the court's only appropriate target in interpretation is the median legislator, which in our view is not the complete story. See infra notes 107-52 and accompanying text. More generally, we agree with Fiorina that committees may 
search for a coherent understanding of a statute must include a careful examination of the work of the relevant committees. That work will be reflected, albeit imperfectly, in the reports, which legislators and staff are likely to read more carefully than the bill itself and therefore may represent part of the congressional understanding of the statute's purpose and meaning. Thus recent public choice scholarship, as well as longstanding political science understandings of congressional committee power, supports the traditional presumption that "very likely most [members of Congress] knew only of the general purpose [of a bill], relied for the details on members who sat on the committees particularly concerned, and were quite willing to adopt these committees' will on subordinate points as their own."

A fundamental aspect of public choice theory-that legislative outcomes often are the result of a "structure-induced equilibrium"98 - does counsel some judicial caution in using legislative history as an interpretive source. Because legislative equilibrium can result from a combination of legislative structures and rules, one bit or fragment of legislative history may have little to do with the overall coherence that has resulted. But when a fundamental aspect of legislative history, such as a committee report, is unimpeached by other interpretive sources and is consistent with the apparent coherent legislative equilibrium, it should be an important, though not conclusive, interpretive source. This approach coincides with our understanding of traditional public law theory. ${ }^{99}$

sometimes be unrepresentative of the legislative body as a whole, and that this may sometimes be reflected in committee reports. This is one of the many reasons why courts should not treat committee reports as sacrosanct. It does not, however, justify Justice Scalia's suggestion that we ignore such reports or systematically devalue them as compared to other aspects of legislative history. Courts will have great difficulty identifying "unrepresentative" committee reports in all but the baldest circumstances; in those instances, the reports ought to be considered less weighty.

In our view, public choice scholarship also has had little to say about other questions concerning judicial use of legislative history. One recent study bas suggested that opponents of a legislative proposal ordinarily have a greater incentive than other legislators to present misleading information. See Austen-Smith \& Riker, Asymmetric Information and the Coherence of Legislation, $81 \mathrm{Am}$. Pol. Sci. Rev. 897 (1987). This insight supports the traditional doctrine that views of opponents of legislation are entitled to little weight in the interpretive process. See, e.g., Ernst \& Ernst v. Hockfelder, 425 U.S. 185, 204 n.24 (1976).

${ }^{87}$ H. Friendly, supra note 87 , at 216 .

${ }^{98}$ See supra text accompanying notes 26-30.

${ }^{89}$ See supra text accompanying notes 83-91. 
That judges can effectively use legislative history does not, of course, ensure that they always do so. We acknowledge that judicial opinions sometimes appear more mechanical than reflective. ${ }^{100}$ In particular, today's standard Supreme Court opinion interpreting a statute brooks little uncertainty: it argues with a straight face that all relevant sources of meaning unambiguously point in the same direction. ${ }^{101}$ Moreover, the Court sometimes seemingly misuses legislative history, exalting it above the statute itself. ${ }^{102}$ These techniques do not necessarily reveal the true paths taken by judges in reaching results; instead, they may be explainable as wooden pieces of advocacy, rather than persuasive pieces of justification. Perhaps they are also understandable as (transparent) devices to "objectify" the opinion by making it appear that Congress, rather than the courts, made the controversial policy choices. ${ }^{103}$ An excel-

${ }^{100}$ Consider Joseph Vining's view of the opinions produced by the Supreme Court: "They are too much things of patchwork, things which seem, on their face, to express more the institutional process of their making than the thinking, feeling, and reasoning of the author and those persuaded with him." Vining, Justice, Bureaucracy, and Legal Method, 80 Mich. L. Rev. 248, 251 (1981).

${ }^{103}$ Every legislation tcacher will have a favorite example. One of ours is BankAmerica Corp. v. Unitcd States, 462 U.S. 122 (1983), where the majority of the Court treated hopelessly ambiguous statutory language, garbled legislative history, and inconsistent administrative interpretations as all compelling one clear result.

Commentators have speculated that Supreme Court opinions are increasingly the product of law clerks, see, e.g., R. Posner, supra note 89, at 102-29; Vining, supra note 100, at 251-52, who may be particularly poorly prepared for handling difficult statutory issues. See Eskridge \& Frickey, supra note 7, at 691-93 (law schools do not adequately provide students with general skills for dealing with statutes); see also R. Posner, supra note 89 , at 336-40 (proposing law school course in legislation for this reason). In any event, Judge Posner has suggested that one reason why today's Supreme Court opinions generally are so long is "because the law clerk does not know what he can leave out. Not being the judge, he is unsure what facts and reasons are essential and he naturally tends to err on the side of inclusion." Id. at 108. In this light, it is understandable, although lamentable, that law clerks less skilled in statutory areas than other matters end up drafting opinions that mechanically treat every conceivable source of statutory interpretation at length and find all of them supportive of the ultimate result.

${ }_{102}$ For example, in Rome v. United States, 446 U.S. 156, 162-69 (1980), the Court considered itself bound by the "unambiguous congressional intent," id. at 169 , rather than resting its opinion primarily on the plain language of the Voting Rights Act. In fact, the language of the statute amply supported the result the Court reached.

${ }^{103}$ Morris Fiorina has suggested that legislators delegate authority to administrative agencies to shift to them the political costs of making sensitive decisions. See Fiorina, Legislative Choice of Regulatory Forms: Legal Process or Administrative Process?, 39 Pub. Choice 33, 46-52 (1982). "By charging an agency with the implementation of a general regulatory mandate, legislators not only avoid the time and trouble of making specific decisions, they avoid or at least disguise their responsibility for the consequences of the decisions ulti- 
lent example of both vices is the majority opinion in United Steelworkers of America v. Weber. ${ }^{104}$

These wrongheaded opinion drafting techniques may occasionally mislead lower court judges-or perhaps even the Justices themselves-about the appropriate methodology of statutory interpretation. ${ }^{105}$ In addition, the opinions are surely subject to criticism from members of Congress. ${ }^{108}$ The remedy needed is not, however, the replacement of some wooden rules with others (for example, don't look at the legislative history if the language of the statute is "clear"). The appropriate reform is to draft opinions that candidly reflect the application of "practical reason." Part III makes some suggestions along these lines and indicates how public choice scholarship might be useful in this regard.

\section{The Role of Legislative Intent}

One important goal in the conventional approach to statutory construction is the ascertainment of legislative intent. ${ }^{107}$ In Parts I and II, we considered two challenges to this conventional approach: the argument that legislative decisionmaking is too incoherent to have an "intent" or "purpose," and the argument that the documentary record used to help determine intent is unreliable. Several prominent jurists have recently made another argument against legislative intent, contending that the legislature's in-

mately made." Id. at 47 . Similarly, judicial opinions stating that Congress "clearly intended the statute to mean X" may be seen as a means of deflecting the political heat of controversial decisions from the courts to Congress.

${ }^{104}$ See 443 U.S. 193 (1979). For an insightful discussion of these sorts of flaws in Justice Brennan's majority opinion, see Eskridge, Dynamic Statutory Interpretation, 135 U. Pa. L. Rev. 1479, 1488-91 (1987). This is not to suggest tbat Weber is necessarily wrongly decided. Eskridge, for example, makes a strong defense of the outcome in that case. See id. at 149294.

${ }^{105}$ In particular, opinions that seem to rely excessively on legislative history may feed the natural inclination of interpreters-judges or the private bar-to skip over difficult statutory language and other interpretive sources and use instead more easily digestible language in the legislative history. "[T] he lazy judge is likely to take tlie legislative history as an excuse for foregoing the difficult problems of statutory analysis which it is his responsibility to meet." Bishin, The Law Finders: An Essay in Statutory Interpretation, 38 S. Cal. L. Rev. 1, 17 (1965); see also Scalia Speech, supra note 63, at 17 (legislative history is tempting to judges because it "provides such easy answers" to "difficult questions").

${ }_{108}$ Thus, in regard to Senator Arinstrong's concerns, see supra note 61, we agree that some judicial opinions indicate that the judges treated committee reports as an authority as good as, if not better than, the language of the statute.

${ }^{107}$ See, e.g., Commissioner v. Engle, 464 U.S. 206, 214 (1984). 
tent is irrelevant even when it can be ascertained.

This argument has appeared in two contexts. First, echoing some earlier commentators, ${ }^{108}$ Justice Scalia and Judge Easterbrook have suggested that the intent of the enacting legislature is irrelevant except to the extent it can be determined from the language of the statute itself. ${ }^{108}$ Second, joined to some extent by Judge Posner, they have more plausibly argued against any reliance on the intent of legislatures as reflected in legislative events subsequent to passage (so-called "subsequent legislative history"). ${ }^{110}$

We disagree with both arguments against the relevance of legislative intent. In the course of our discussion, we sketch a simple model of statutory construction based on elementary decision theory and informed by practical reason. Although the model is quite elementary, it provides a structure for a flexible approach to statutory interpretation.

\section{A. The Relevance of Legislative Intent}

Doubts about the appropriate use of legislative history in statutory interpretation are not new, ${ }^{111}$ and they have been sounded again rather recently by a prominent legislation scholar. ${ }^{112}$ Perhaps the starkest attack sounds in the raw constitutional language of Marbury v. Madison: the legislature's job is to enact words in statutory form, and the court's job is to say what those statutory words

\footnotetext{
${ }^{108}$ See Radin, Statutory Interpretation, 43 Harv. L. Rev. 863, 871-72 (1930); 2A N. Singer, Statutes and Statutory Construction $\S 45.07$, at 29 (4th ed. rev. 1984).

100 See infra text accompanying notes 114-27.

110 See infra text accompanying notes 145-49.

111 See, e.g., United States v. Public Utils. Comm'n, 345 U.S. 295, 319-21 (1953) (Jackson, J., concurring); Scliwegmann Bros. v. Calvert Distillers Corp., 341 U.S. 384, 395-97 (1951) (Jackson, J., concurring); Jackson, The Meaning of Statutes: What Congress Says or What the Court Says, 34 A.B.A.J. 535, 537-38 (1948); Landis, A Note on "Statutory Interpretation," 43 Harv. L. Rev. 886, 888-90 (1930); Radin, supra note 108, at 872-73. Tlie loariness of the dispute is illustrated by comparing Cluurch of the Holy Trinity v. United States, 143 U.S. 457, 459 (1892) ("spirit" of a statute, slown partially by its legislative history, controls over seemingly clear statutory language) with Caminetti v. United States, 242 U.S. 470, 485 (1917) (when statutory language is plain, legislative listory may not be examined).

112 See R. Dickerson, The Interpretation and Application of Statutes 137-97 (1975); Dickerson, Statutory Interpretation: Dipping into Legislative History, 11 Hofstra L. Rev. 1125 (1983). For very recent judicial commentary, see Mikva, A Reply to Judge Starr's Observations, 1987 Duke L.J. 380; Starr, Observations About tle Use of Legislative History, 1987 Duke L.J. 371.
} 
mean without reference to the intentions of legislators. ${ }^{113}$ More recently, Justice Scalia has argued strenuously that legislative intent is irrelevant to statutory construction. Because the 1985-86 speech in which he has made this argument has not been widely available, we will quote it at some length:

If I were writing on a blank slate, I suppose I would call into question the fundamental premise upon which all use of legislative history is based-the generally accepted proposition, as expressed in a Columbia Law Review article on the subject, that "interpretative doubts . . . are to be resolved by judicial resort to an intention entertained by the lawmaking body at the time of its enactment." "114

Several considerations would justify contesting this proposition, and replacing it with the thesis that interpretative doubts are to be resolved by assessing the meaning that would reasonably have been conveyed to a citizen at the time the law was enacted, as modified by the relationship of the statute to later enactments similarly interpreted.

This thesis is suggested, first, by the constitutional ideal set forth explicitly in the Massachusetts Constitution, but certainly underlying the Federal Constitution as well-of "a government of laws not of men." What does this mean if a statute is to be interpreted not according to its most plausible objective import, but according to the unlegislated "intent" of those who enacted it?

The thesis is also supported by the doctrine of separation of powers, which the Massachusetts Constitution describes as the principal support of a government of laws. Surely it is more consonant with that doctrine that-once a statute is enacted-its meaning is to be determined on the basis of its text by the Executive officers cliarged with its enforcement and the Judicial officers charged with its application.

And finally, the thesis is supported by the primary principle

\footnotetext{
113 "It is emphatically the province and duty of the judicial department to say what the law is." Marbury v. Madison, 5 U.S. (1 Cranch) 137, 177 (1803). Holmes once wrote that "[w] do not inquire what the legislature meant; we ask only what the statute means." $0 . W$. Holmes, Theory of Legal Interpretation, in Collected Legal Papers 207 (1920). But Holmes also wrote, this time in a judicial opinion, that "the general purpose is a more important aid to the meaning than any rule which grammar or formal logic may lay down." United States v. Whitridge, 197 U.S. 135, 143 (1905).

${ }^{114}$ Jones, Statutory Doubts and Legislative Uncertainty, 40 Colum. L. Rev. 957, 965 (1940) (correctly reading as follows: "interpretative doubts . . . are to be resolved by judicial resort to an 'intention' entertained by the members of the lawmaking body at the time of enactment").
} 
governing the use of legislative history-which is repeatedly recited without apparent realization that it undercuts all use of legislative history at all-to wit, the principle, that where the text of the statute is clear, legislative history is not to be consulted. Why in the world should that be so, if the actual intent of the enacting legislature is the touchstone? ${ }^{115}$

In short, Justice Scalia would replace the current approach to statutory construction with a "four corners" rule, under which the meaning of a statute would be determined solely on the basis of statutory language. As a Justice, Scalia has apparently adhered to these views: "Judges interpret laws rather than reconstruct legislators' intentions. Where the language of those laws is clear, we are not free to replace it with an unenacted legislative intent."116 As Justice Scalia candidly admits, his proposal would not rigorously constrain "judicial willfulness."117

Judge Easterbrook has also argued on occasion that judges should not attempt to discover legislative intent-except to the extent it can be discerned from the statutory language-at least where the issue before the court is whether the statute applies to a transaction. ${ }^{118} \mathrm{He}$ argues that giving weight to unenacted legislative intent allows the legislature to circumvent the constitutional requirements of bicameral passage and presentment to the President. ${ }^{119}$ His concern, as he explains in a recent opinion, is that "a transmutation from 'intent' to law bypasses the processes that form the heart of the constitutional method of legislation."120

These contentions posit a dichotomy between clear statutory language and "unenacted" legislative intent and assume that the former must always trump the latter. Yet the reporters are filled

115 Scalia Speech, supra note 63, at 15-16 (emphasis in original).

${ }_{116}$ Immigration \& Naturalization Serv. v. Cardoza-Fonseca, 107 S. Ct. 1207, 1224 (1987) (Scalia, J., concurring in the judgment); see also Citicorp Indus. Credit, Inc. v. Brock, $107 \mathrm{~S}$. Ct. 2694, 2702 (1987) (Scalia, J., concurring) (plain meaning of statute controls notwithstanding any legislative purpose inconsistent with it).

11 Scalia Speech, supra note 63, at 17.

118 See Easterbrook, supra note 19, at 549-50. As before, we leave to others the task of reconciling the somewhat conflicting views Judge Easterbrook has presented elsewhere. See Farber \& Frickey, supra note 2, at 881 n.49.

119 Easterbrook, supra note 19; at 539, 549.

${ }^{120}$ Premier Elec. Constr. Co. v. National Elec. Contractors Ass'n, 814 F.2d 358, 365 (7th Cir. 1987); see also Federal Election Comm'n v. Rose, 806 F.2d 1081, 1090 (D.C. Cir. 1986) (courts sbould ordinarily confine tbemselves to statutory language). 
with cases in which courts have failed to adhere to this supposed rule, often because of the countervailing weight of the legislative history. ${ }^{121}$ Even seemingly crystal-clear statutory language does not always prevail. In our view, this result occurs because statutory interpretation involves a myriad of interpretive sources in potential tension-statutory language, any specific indications of legislative intentions, the court's best guess as to what the legislature would have done had it been forced squarely to address the issue at bar, the competing overall purposes that might fairly be attributed to the statute, and the "best answer" to the interpretive problem in light of the overall fabric of the current law and society. ${ }^{122}$ It is the judicial art to wrestle with these various sources and reach an accommodation-an "interpretation"-consistent with the norms of the American legal interpretive community. ${ }^{123}$

As this explanation suggests, we see statutory interpretation as an exercise in "practical reason" rather than foundationalist methodology. More specifically, such interpretation is a mixture of inductive and deductive reasoning based on a combination of arguments that seem most persuasive in context, not the inexorable outcome of some pre-established formula. ${ }^{124}$ This is, however, not the place for a full-blown theory of statutory interpretation and practical reason. Instead, our more modest task is to demonstrate that, notwithstanding the attacks of Justice Scalia and Judge

${ }^{121}$ One of the best-known examples is Church of the Holy Trinity v. United States, 143 U.S. 457 (1892). There the Court stated:

It is a familiar rule, that a thing may be within the letter of the statute and yet not within the statute, because not within its spirit, nor within the intention of its makers. This has been often asserted, and the reports are full of cases illustrating its application. This is not the substitution of the will of the judge for that of the legislator, for frequently words of general meaning are used in a statute, words broad enough to include an act in question, and yet a consideration of the whole legislation, or of the circumstances surrounding its enactment, or of the absurd results which follow from giving such broad meaning to the words, makes it unreasonable to believe that the legislator intended to include the particular act.

Id. at 459. One "circumstance[] surrounding its enactment" weighed heavily by the Court was the legislative history. Id. at 464-65.

${ }^{122}$ For an overview and analysis of these interpretive sources, see W. Eskridge \& P. Frickey, supra note 18, at 569-635.

${ }_{123}$ See generally S. Burton, An Introduction to Law and Legal Reasoning 125-43, 204-14 (1985) (role of legal community. in legitimating judicial decisions).

124 For an overview of the contrasts between practical reason and foundationalist approaches, see Farber \& Frickey, Practical Reason and the First Amendment, 34 UCLA L. Rev. (forthcoming 1988). 
Easterbrook, legislative intent deserves a place in the interpretive effort, without attempting at this point to define precisely what role it should play. ${ }^{125}$

The Scalia-Easterbrook arguments might apply with some force when a statute is unambiguous on its face, although even there room exists for doubt. ${ }^{126}$ But where a reader could reasonably attribute more than one meaning to the statute, tbe Scalia-Easterbrook arguments misfire. When statutory language could have one of several meanings, the ideal of "government by laws" is irrelevant, because our problem is precisely that we don't know what the "laws" require. Furthermore, so long as the materials on which judicial interpretation is based are available to both Houses of Congress and to the President, the decision by each entity as to whether to approve a bill can be based on an appraisal of the bill's probable judicial interpretation. Hence, the article I procedural requirements are fully satisfied. It is also irrelevant that courts and agencies rather than legislators are in charge of implementing statutes, for their practices must be consistent with the meaning of the statute, and that meaning is the precise issue.

Thus, one fundamental flaw in the Scalia-Easterbrook conception is its assumption that statutes have a legal meaning that exists before the process of statutory interpretation. If this were true, then anything "added" in the process of construction arguably would be an illegitimate change in the pre-existing meaning. An

${ }^{125}$ In the next subsection, we speculate on how legislative intent might influence statutory interpretation, based on elementary decision theory. See infra text accompanying notes 136-52.

${ }^{126}$ For example, the legislative record may make it clear that the statutory language includes a typographical error, and that both Houses as well as the President overlooked the error. Separation of powers does not seem to be a problem in such a situation. More generally, when statutory language points in a dubious direction-one that is, for example, strongly counter to any actual legislative intent, to what the legislature probably would have intended if it had thought about the problem, to the purposes that might reasonably be attributed to the statute, and to the "best answer" based on the overall fabric of law and life-courts ought to be reluctant to give that language full force. That the Supreme Court waffles on this problem is clear. See Note, Intent, Clear Statements, and the Common Law: Statutory Interpretation in the Supreme Court, 95 Harv. L. Rev. 892 (1982). Compare, e.g., Offshore Logistics, Inc. v. Tallentire, 447 U.S. 207 (1986) and Church of the Holy Trinity v. United States, 143 U.S. 457 (1892) (both deviating from plain meaning of statutory language to reach arguably "best answer") with United States v. Locke, 471 U.S. 84 (1985) and Griffin v. Oceanic Contractors, Inc., 458 U.S. 564 (1982) (both refusing to deviate from plain meaning). 
ambiguous statute, however, lacks any clear pre-existing meaning. In any context in which its meaning is relevant, that meaning is necessarily the result of the interpretive process. As Judge Posner has said, "We cannot escape interpretation."127 Thus, although the norms cited by Justice Scalia and Judge Easterbrook require that courts be faithful to the meaning of the statute, they say little or nothing about how to determine that meaning when it is in doubt.

Public choice theory, with its emphasis on the purposeful nature of legislators' conduct, ${ }^{128}$ also suggests that the "four corners" rule would have undesirable practical effects. Under the current approach, Congress can act with the assurance that courts will attend to the legislative intent, which decreases the probability that statutes will be implemented contrary to the goals of the legislators. Congress can be expected to modify its behavior in several ways in response to a less hospitable judicial environment.

First, a "four corners" rule raises the costs of drafting legislation by increasing the penalties for ambiguities. Thus, Congress will be required to invest additional resources in drafting. The resultant, less ambiguous statutes will also leave administrative agencies less leeway, undercutting Justice Scalia's desire to broaden agency discretion in statutory implementation. ${ }^{129}$

Second, because statutes will be more frequently interpreted contrary to legislative intent, Congress will more often be required to pass corrective legislation. Passing this additional legislation involves significant transaction costs. Congress will also be forced to devote additional resources to monitoring administrative agencies and pressuring them to interpret ambiguous statutes in conformity with legislative intent, rather than relying on the judiciary to perform part of this role. ${ }^{130}$

${ }^{127}$ Posner, supra note 20, at 193.

128 See Farber \& Frickey, supra note 2 , at $878,888-89$, 891. See generally Easterbrook, Foreword: The Court and the Economic System, 98 Harv. L. Rev. 4, 14, 60 (1984) (individuals will adapt to circumvent rules that thwart them).

${ }^{129}$ Justice Scalia has been an advocate of giving agencies a leading role in interpreting statutes. See Immigration \& Nationalization Serv. v. Cardoza-Fonseca, 107 S. Ct. 1207, 1224-25 (1987) (Scalia, J., concurring in the judgment).

${ }^{130}$ See R. Posner, supra note 89 , at 292-93. Justice Scalia points out that legislative history is disregarded in England. See Scalia Speech, supra note 63, at 1-2. The costs discussed in the text are inuch lower in a parliamentary system, however, particularly in an effectively unicameral one with strict party discipline. Passing corrective legislation, for instance, is much easier. 
Third, by increasing the need for detailed, unambiguous drafting, as well as the risk that legislation will be applied in unintended ways, a "four corners" rule would tend to discourage additional legislation. This is not necessarily desirable even for conservatives like Justice Scalia and Judge Easterbrook, who generally disfavor government regulation, because one effect would be to freeze current regulatory schemes in place.

Fourth, recourse to legislative history and other indicia of legislative intent often can provide a simple way of answering what would otherwise be difficult questions of statutory construction. Even if the answer given by these sources is sometimes arbitrary, having a ready answer is itself valuable. It is a truism, but nevertheless valid, that having a clear answer is often more important than having a correct answer, for judges, lawyers, and ordmary citizens. ${ }^{131}$

Apart from its potential practical impact, the "four corners" rule should be rejected for more fundamental reasons. It is contrary to the important ideal, favored by Judge Easterbrook on other occasions, of the courts as "honest agents of the pohtical branches," engaged in "faithfully executing decisions made by others." 132 Consider a member of the President's staff who receives an ambiguous directive from the President about how to handle an important issue. The staff member considers two methods of interpretation. The first is to consider what the President said about his purposes and intentions to another staff member. The second is to pick the interpretation of the language that would seem most compelling to the "reasonable citizen" who knew nothing about the President's desires. An honest and faithful agent of the President surely would not apply the latter, "four corners," approach-indeed, that approach to interpretation would be far more appealing to an obstructive bureaucrat eager to sabotage a presidential program than to a staff member loyal to the President.

This example also suggests another important objection to the

\footnotetext{
131 Justice Scalia indicated that extensive research into legislative history can be timeconsuming and expensive. See Scalia Speech, supra note 63, at 14-15. We agree that this is a problem. Our response would be to de-emphasize the use of materials other tban committee reports, because these reports are much more accessible and compact tban other sources of legislative history. Justice Scalia would presumably object to sucb an approacb because be views committee reports as the least reliable source of legislative history. See id. at 18.

${ }^{132}$ Easterbrook, supra note 128, at 60.
} 
"four corners" rule. The President's legitimacy derives from his election by the people. Thus, his directives ultimately claim support on the basis of his democratic selection-the people chose him to make certain decisions. When he makes these decisions he acts as their delegate, at least in some formal sense. If a staff member knowingly interprets an ambiguous directive contrary to the President's actual intent, then the action he takes does not truly stem from the President's choice and hence cannot claim legitimacy as a decision by the people's delegate. The unelected staff member is simply taking advantage of poor drafting to implement a policy that is only fortuitously related to any decision by the President. Thus, the staff member who knowingly ignores the elected drafter's intent strains the chain of legitimacy from the electorate to the drafter and then to the implementor. Similarly, when a court ignores congressional intent in implementing a statute, it weakens the legitimacy of the statute by detaching the implementation from the actual purposes of the electorate's representatives.

What, then, of the unambiguous statute? Justice Scalia contends that if legislative intent were crucial, we would allow it to override even clear statutory language. ${ }^{133}$ While overriding clear language is not unheard of, it is certainly exceptional. ${ }^{134}$ This deference to unambiguous language in no way undercuts the primacy of legislative intent. As an evidentiary matter, unambiguous language is very strong evidence of intent and should normally outweigh less probative evidence such as legislative history. If courts were to make a frequent practice of making decisions contrary to clear statutory language, the long-run effect could be to decrease the implementation of congressional intent by depriving Congress of its best tool for communicating that intent. Thus, a presumptive "plain language" rule is no more contrary to an emphasis on the drafter's intent here than it is in contract law. ${ }^{136}$ In both fields of law, such a rule sometimes frustrates the drafter's intent but is believed to

${ }^{133}$ See Scalia Speech, supra note 63, at 16.

134 See, e.g., Wald, Some Observations on the Use of Legislative History in the 1981 Supreme Court Term, 68 Iowa L. Rev. 195, 199 (1982). On the current status of the "plain meaning" rule, see id. at 197-99; Note, supra note 126.

${ }^{133}$ For an informative discussion of the corresponding problem in contract law, see Goetz \& Scott, The Limits of Expanded Choice: An Analysis of the Interactions Between Express and Implied Contract Terms, 73 Calif. L. Rev. 261 (1985). 
implement that intent more often and more efficiently than any other rule of interpretation.

\section{B. Betting on Legislative Intent: A Model of Statutory Construction}

Although we do not take the position that legislative intent should always be controlling in statutory construction, we do believe that it plays a central role. Consequently, without making a full commitment to an original intent theory, we believe that developing a better model of intent-based interpretation is useful.

Judge Posner's "communication" theory of legislation is a helpful starting point. Judge Posner argues that in construing legislation, judges are attempting to decode communications from their legislative superiors. Making a military analogy, he suggests that the judge is in the same position as the military officer attempting to apply obscure directions from headquarters:

In our system of government the framers of statutes and constitutions are the superiors of the judges. The framers communicate orders to the judges through legislative texts (including, of course, the Constitution). If the orders are clear, the judges must obey them. Often, however, because of passage of time and change of circumstance the orders are unclear and normally the judges cannot query the framers to find out what the order means. The judges are thus like the platoon commander in my example. It is irresponsible for them to adopt the attitude that if the order is unclear they will refuse to act. They are part of an organization, an enterprise-the enterprise of governing the United States-and when the orders of their superiors are unclear, this does not absolve them from responsibility for helping to make the enterprise succeed. The platoon commander will ask himself, if he is a responsible officer: what would the company commander have wanted me to do if communications failed? Judges should ask themselves the same type of question when the "orders" they receive from the framers of statutes and constitutions are unclear: what would the framers have wanted us to do in this case of failed communication? ${ }^{136}$

Thus, in Judge Posner's view, the task of the judge is to ascertain the most likely intention of the drafters.

The idea of a statute as an unclear communication can be easily

${ }^{138}$ Posner, supra note 20 , at $189-90$. 
translated into a model by assuming that the statute has a number of interpretations (each of which is unambiguous); the problem is that the recipient is unsure of which interpretation is intended. Let us call the various interpretations $x_{1}, x_{2}, x_{3}, \ldots x_{n}$. Some of the interpretations are more probable than others as descriptions of the drafter's actual intent. Let $p\left(x_{i}\right)$ represent the probability that the $i$ th interpretation corresponds to the drafter's actual intent, taking into account the phrasing of the statute, its legislative history, and other aspects of historical context. ${ }^{132}$

One interpretation of Judge Posner's thesis is that the court should pick the interpretation that has the greatest likelihood of being correct. Thus, in terms of our formal model, the court would pick $\mathrm{x}_{\mathrm{i}}$ so as to maximize $\mathrm{p}\left(\mathrm{x}_{\mathrm{i}}\right)$. To make things simple, suppose the $\mathrm{x}_{\mathrm{i}}$ are listed in decreasing order of probability. Then Judge Posner's rule apparently would be always to pick $x_{1}$, the choice which has the highest likelihood of being correct.

This is not always a reasonable method of decisionmaking. Initially, it gives no guidance at all when the probabilities are equal-for instance, when we have no information at all about legislative intent. It also gives potentially misleading guidance when the probabilities are close. Suppose, for example, that there are two possible interpretations, with $\mathrm{p}\left(\mathrm{x}_{1}\right)=.51$ and $\mathrm{p}\left(\mathrm{x}_{2}\right)=.49$. One is slightly more probable than the other and, in the absence of any other information, would be chosen. Suppose, however, that we also know that the consequences are much different. Rational decisionmaking under uncertainty requires that we take those consequences into account in choosing between risky alternatives. ${ }^{138}$ For

137 Professor Fiorina has suggested a similar formulation in a model dealing with legislative responses to uncertainties about how a law will be applied. See Fiorina, supra note 103, at 56-57.

${ }^{138}$ See Kaplan, Decision Theory and the Factfinding Process, 20 Stan. L. Rev. 1065, 106669 (1968). As a general matter, decision theory indicates that the rational choice under uncertainty is to maximize the expected value of the utility of the outcome. See E. Stokey \& R. Zeckhauser, A Primer for Policy Analysis 237-54 (1978). Here, the outcomes are that the chosen interpretation either corresponds to or violates the actual legislative intent. We can assume that the payoff is always higher when the interpretation is actually correct, but the exact way to model the payoff as a function of outcomes and correctness is unclear. In the text, we will choose the simplest method: to assume that the judge's payoff is zero when he chooses the wrong alternative, and that when he is correct the payoff varies depending on the alternative in question. This is a highly "original intent"-oriented assumption because a statutory interpretation is treated as valueless if it does not in fact correspond with legislative intent. One result is that the judge will never chose an interpretation which is known to 
example, in interpreting a partner's bid in bridge, a player would take into account not only how likely the partner is to have various possible hands but also the consequences of adopting each interpretation; some mistakes may be much more costly than others.

To return to Judge Posner's platoon leader, suppose that because of radio static the platoon leader is unsure of whether he has been ordered to attack or to retreat. The order sounded a little more like "charge," but the effect of an attack might be to wipe out his unit, whereas a retreat would seem more sensible. A responsible officer would not, we think, decide which course to take without considering the consequences. ${ }^{139}$ Within the constraints of his orders, the officer does bear the responsibility for the consequences of his decision. On the other hand, if the order had been clear, the officer would presumably have obeyed it even if the consequences seemed undesirable.

In effect, the judge is betting on the legislature's actual intention and must take into account both the odds of being right and the consequences of being wrong. To simplify the situation enough to allow construction of a formal model, we might think of the various interpretations as boxes, only one of which contains a prize. The judge is uncertain about the nature of the prize, which can vary depending upon its location (a larger box, for example, could contain a bigger prize). The judge also has fuzzy information about which box contains the prize, which he can translate into a list of

\footnotetext{
be wrong $\left(\mathrm{p}\left(\mathrm{x}_{\mathrm{i}}\right)=0\right)$. Although modifying this assumption would allow a greater degree of judicial lawmaking, a modification might be reasonable when practical considerations militate extremely strongly against implementing the legislature's actual intent in an old statute. (Rational legislators would attach much less importance to events in the far future, for example. See Fiorina, Group Concentration and the Delegation of Legislative Authority, in Regulatory Policy and the Social Sciences 175, 193 (R. Noll ed. 1985)).

139 Judge Posner might well respond that headquarters would presumably undertake the same evaluation of the consequences of each choice. Hence, the platoon leader could take the consequences into account in deciding what headquarters would want him to do after receiving a garbled message. Similarly, a judge could ask himself, "What would the legislature have wanted me to do in these circumstances where the statute is ambiguous and the consequences of the various interpretations are such-and-such?" See Posner, supra note 20, at 200 . Often, this kind of analysis would lead to the same results as that advocated in the text, but we believe our analysis is more candid. The legislature's hypothetical intent about how to construe ambiguities in varying circumstances is so speculative that the answer is almost sure to be the same as the judge's own preferences about the consequences of interpretation. Cf. Levin, Identifying Questions of Law in Administrative Law, 74 Geo. L.J. 1, 22 n.129 (1985) (considering hypothetical congressional intent concerning scope of judicial review of administrative action).
} 
probabilities. Under these circumstances, decision theory suggests that the judge maximize the expected value of the prize by multiplying the probability that a given box has the prize by the value of the prize associated with that box.

This analysis suggests the following modification of the initial Posner model. Let $\mathrm{v}\left(\mathrm{x}_{\mathrm{i}}\right)$ measure the desirability of the payoff that results from construing the statute in accordance with interpretation $x_{i^{*}}{ }^{140}$ Then a rational judge should pick the interpretation that maximizes $\mathrm{u}\left(\mathrm{x}_{\mathrm{i}}\right)=\mathrm{p}\left(\mathrm{x}_{\mathrm{i}}\right) \mathrm{v}\left(\mathrm{x}_{\mathrm{i}}\right)$. In other words, the payoff associated with each interpretation should be discounted by the likelihood that it is correct.

True to its interpretivist origins, this model never leads the judge to ignore clear legislative intent. If you know which box the prize is in, you always pick that box. Suppose the legislative intent is completely clear, and corresponds to interpretation $x_{j}$. Then we must have $p\left(x_{j}\right)=1$ and $p\left(x_{i}\right)=0$ for all $i$ not equal to $j$. As a result, $u\left(x_{i}\right)$ vanishes except at $i=j$, so $j$ is the choice. In case of a tie regarding legislative intent, however, the judge would pick the most beneficial interpretation of the statute. ${ }^{141}$ In intermediate cases, the outcome is determined both by the likelihood that an interpretation corresponds with the drafter's intent and by the consequences of adopting the interpretation.

By allowing the judge to consider the consequences of adopting an interpretation, this rule permits some degree of judicial flexibility. ${ }^{142}$ How much judicial authority is entailed depends on how we define the payoff, $v\left(\mathrm{x}_{\mathrm{i}}\right)$. We could include the full social consequences of adopting an interpretation, so that the judge would consider the full range of consequences that a legislature would consider. In considering these consequences, judges might consult their own preferences, the view of the legislature of the time, or current social mores. On the other hand, $v\left(x_{i}\right)$ could be defined much more narrowly to include only "legal process" costs of vari-

\footnotetext{
${ }^{140}$ At this point, we are not making any effort to define how to measure these payoffs. By adjusting the origin if necessary, we will make $v\left(x_{i}\right)$ greater than zero.

${ }^{141}$ For an example of something like this situation, see Standard Office Bldg. Corp. v. United States, 819 F.2d 1371, 1379 (7th Cir. 1987) (opinion written by Judge Posner).

${ }^{142}$ The model also has the advantage of greater candor because, as Judge Posner points out, the legislative intent is often unknown and the decision must actually turn on other factors. We agree with him that judicial opinions more candidly acknowledging the use of other factors would be desirable. See Posner, supra note 7, at 777-78.
} 
ous kinds, such as stare decisis factors, impact on the implementation of other statutes, and other relatively neutral judicial policies. In any event, no matter low $\mathrm{v}\left(\mathrm{x}_{\mathrm{i}}\right)$ is defined, the court will never disobey a clear directive from the legislature. The judge's actual decision is always constrained by $p\left(x_{i}\right)$, which brings into play whatever is known about the legislature's actual intentions. Thus, the model introduces a certain degree of flexibility while maintaining the principle of legislative supremacy. ${ }^{143}$

This elementary model lias at least lieuristic value. It captures some-but, we hasten to emphasize, not all-of the use of "practical reason" to interpret statutes. Althougl building on Judge Posner's useful communication model of statutory construction, it gives more realistic insiglit into the problem of decoding unclear messages. When deciding between various interpretations of an unclear message, both the probability of a given interpretation and its consequences must be considered. As we will see in the next section, the model sliows how judges committed to legislative intent as a touchstone can still consider post-enactment developments.

\section{The Problem of Subsequent Legislative History}

When construing a statute, a court will commonly be confronted with evidence about later legislative events. For example, the legislature may have readopted a statute after it had been construed by the courts, with committee reports commenting on the judicial decisions. Also, later legislative history may indicate a view by members of Congress (such as an important committee or the sponsors of the original legislation) about low an existing law should be interpreted. Finally, Congress may have declined to amend a statute after the courts had construed it. The traditional approach to stat-

\footnotetext{
${ }^{143}$ This model could be usefully elaborated in several directions. It would be interesting to couple this model of judicial interpretation with various models of legislation to determine how rational legislators would respond to the model. Another option would be to make the determination of $\mathrm{p}\left(\mathrm{x}_{\mathrm{j}}\right)$ more explicit, for example by building in a Bayesian analysis in which legislative history modifies a prior estimate of probability based solely on statutory language. The whole topic of judicial interpretation has received very little attention from formal modelers. We can imagine (but have not attempted to construct) more elaborate models of cooperative games between judges and legislatures or perhaps the application of communication theory to the problem. We encourage those with greater technical expertise to pursue these options.
} 
utory construction gives varying degrees of weight to such subsequent history, depending on the type of subsequent event involved and on the context. ${ }^{144}$

Forceful arguments have been made that subsequent legislative history should be completely ignored. Judge Posner argues that to give weight to the preferences of later legislators would be to undermine the controlling intent of the enacting legislature, unravelimg the legislative deal embodied in the statute. ${ }^{145}$ In several opinions, Justice Scalia has also argued strenuously against giving weight to legislative events post-dating enactment. ${ }^{146}$ Use of subse-

${ }^{144}$ See Johnson v. Transportation Agency, Santa Clara County, California, 107 S. Ct. $1442,1450 \mathrm{n} .7$ (1987) (inferring congressional agreement with a prior decision from fact that no bills were introduced to change result im highly publicized, controversial case); Bob Jones Univ. v. United States, 461 U.S. 574, 599-602 (1983) (inferring congressional acquiescence to an IRS policy from congressional inaction and enactment of a related amendment); Consumer Prod. Safety Comm'n v. GTE Sylvania, Inc., 447 U.S. 102, 117-19 (1980) (stateinents in Conference Report on 1976 amendments entitled to little weight in construing 1972 statute); Seatram Shipbldg. Corp. v. Shell Oil Co., 444 U.S. 572, 595-96 (1980) (giving weight to a 1971 committee report in construing a statute amended in 1938 because intent of enacting Congress was obscure); Wald, supra note 134, at 205 (courts make too inuch use of subsequent legislative history); cf. W. Eskridge \& P. Frickey, supra note 18, at 752-60 (discussing and providing examples of the use of post-enactment legislative history).

${ }^{145}$ See R. Posner, Economic Analysis of Law 501 (3d ed. 1986); Posner, Statutory Interpretation-in the Classrooln and in the Courtroom, 50 U. Chi. L. Rev. 800, 809-10 (1983); Posner, Economics, Politics, and the Reading of Statutes and the Constitution, 49 U. Chi. L. Rev. 263, 275 (1982). His skepticism about suhsequent legislative history is also reflected in his opinion in Olson v. Paine, Webber, Jackson \& Curtis, Inc., 806 F.2d 731, 741-42 (7th Cir. 1986). Yet he has not adopted an absolute prohibition on the consideration of all forms of subsequent legislative history. See Telegraph Sav. \& Loan Ass'n. v. Schilling, 807 F.2d 590, 593 (7th Cir. 1986).

${ }^{146}$ See United States v. Johnson, 107 S. Ct. 2063, 2075 (1987) (Scalia, J., dissenting) (Congress' failure to amend statute after Supreme Court interpretation of it cannot ratify the interpretation); Johnson v. Transportation Agency, Santa Clara County, California, 107 S. Ct. 1442, 1472-73 (1987) (Scalia, J., dissenting) ("vindication by congressional inaction is a canard"); Hirschey v. Federal Energy Regulatory Comm'n, 777 F.2d 1, 8 (D.C. Cir. 1985) (Scalia, J., concurring) (statements in committee report dealing with unamended portion of prior law entitled to little weight); Gott v. Walters, 756 F.2d 902, 914-15 (rejecting use of subsequent legislative history as nonprobative), reh'g granted and opinion vacated, 791 F.2d 172 (D.C. Cir. 1985). Justice Scalia has also strongly endorsed the presumption against inplied repeal because it prevents legislative gamesmanship, with various legislators gambling on whether a new statute would displace various prior laws. United States v. Hansen, 772 F.2d 940, 944, 948 (D.C. Cir. 1985), cert. denied, 106 S. Ct. 1262 (1986). The effect of this presumption is to "help preserve the original legislative bargain from collateral attack." Comment, The Appellate Jurisprudence of Justice Antonin Scalia, 54 U. Chi. L. Rev. 705, 722 (1987). The combined result of his rejection of subsequent legislative history and his implied-repeal rule is to largely insulate earlier statutes against modifications by later legal developments. 
quent legislative history, he maintains, "is based, to begin with, on the patently false premise that the correctness of statutory construction is to be measured by what the current Congress desires, rather than by what the law as enacted meant."147 Judge Easterbrook has also contended that allowing subsequent events to alter the meaning of a statute would amount to "dishonoring the procedural aspects of the legislative process." ${ }^{148}$ Unless Congress actually enacts new legislation, "nothing happens," and "[t]he world goes on as before."149

Even within an "original intent" approach to statutory construction, this complete rejection of subsequent history goes a little too far. Under the model developed in the preceding subsection, subsequent legislative events may be significant, not as controlling legislative intent, but as factors relevant to determining the consequences of adopting various interpretations of ambignous statutes.

One possible set of consequential costs associated with adopting an interpretation relates to the probability of that interpretation being rejected by the legislature. Not only does a rejection impose needless transaction costs on the legislature, but it may make the court look bad, both in the eyes of the public and of the legislators. As is true of legislative history generally, some deference to subsequent legislative history avoids undesirable responses by the legislature, such as higher drafting costs when legislation is amended or readopted (to ratify explicitly all existing judicial interpretations), more frequent action by the legislature, and so forth. Thus, some consideration of subsequent legislative history can be defended on much the same ground as the doctrine of stare decisis: it does not deny the ultimately controlling effect of the enacting legislature's intent; rather, it takes into account the effect of later judicial rulings on settled expectations.

Subsequent legislative history can also serve at least two other purposes. First, to the extent that the effects of various interpretations are relevant, subsequent legislative history can help the judge determine current societal norms, so that his appraisal of $v\left(x_{i}\right)$ (the effect of adopting an interpretation) will not simply represent his

147 Johnson v. Transportation Agency, Santa Clara County, California, 107 S. Ct. 1442, 1472-73 (1987) (Scalia, J., dissenting).

${ }^{148}$ Easterbrook, supra note 19, at 539.

149 Id. 
own personal preferences. ${ }^{150}$ Second, subsequent legislative action-as opposed to mere legislative history-may be another source of operative legislative intent, which will have to be reconciled with the intent underlying earlier statutes. The upshot is that even an original intent perspective has room for evolving statutory interpretation. ${ }^{151}$

The heuristic model we have proposed here suggests the complexity of statutory construction. The model is not intended to reduce statutory construction to a formula. Quite the contrary, it is intended to show that even within an original intent framework, and even with a rigorously simplified model, decisions should take into account more than a simple estimate of legislative intent. In construing a statute, a judge must consider a wide variety of factors, including the statutory language, whatever evidence of legislative intent is available, the effect of a given interpretation on other parts of the legal system, and the societal effect of the interpretation. No pre-set method exists for combining these factors; rather, the exercise of prudence and practical reason is required. ${ }^{162}$

\section{Conclusion}

By jettisoning the concept of legislative intent and limiting the use of legislative history, Justice Scalia and his followers would distort the relationship between courts and legislatures. The legislature would become merely the source of statutory verbiage, which courts would implement in disregard of the legislative purpose. This effort to keep the creators of the legislation at arms' length-indeed, denigrating their integrity while exalting the product of their labors-seems unhealthy in a representative democracy. Consequently, we believe it would be unwise to adopt Justice Scalia's proposals.

One of our basic objections to these proposals is that they are too reductionist. In effect, Justice Scalia and some of his fellow Reagan appointees have attempted to narrow the range of tools

\footnotetext{
${ }^{250}$ Some of Justice Stevens' opinions are suggestive in this regard. See, e.g., Runyon v. McCrary, 427 U.S. 160, 191-92 (1976) (Stevens, J., concurring).

${ }^{151}$ Cf. Eskridge, supra note 104 (arguing that sometimes older and vaguer statutes should be interpreted to reflect recent mores).

${ }^{152}$ Judge Posner's most recent writings seem to reflect a growing emphasis on practical reason in statutory construction. See Posner, supra note 20, at 217.
} 
available to judges in construing statutes by eliminating any use of committee reports or subsequent legislative history. In our view, this is a step in the wrong direction; judges need as many tools as possible to help them in the difficult task of applying statutes.

Ultimately, to say that a case involves statutory interpretation is to say little more than that a statute is someliow relevant to a court's decision. The range of statutes is extraordinary-it includes everything from the Internal Revenue Code to the Uniform Commercial Code to the Minnesota Fetal Disposal Act. Moreover, the ways that these statutes can be relevant are also numerous: a statute can give rise to a cause of action or a defense; it can provide a useful analogy or create a presumption; and it can occasionally modify a result that would otherwise be required by the Constitution, as in some eleventh amendment cases. Legislatures themselves are equally diverse: the East Cleveland City Council may liave little in common with the United States House of Representatives; indeed, the House of 1987 bears little resemblance to that of 1887 . We see no reason to believe that a single formula can provide the answer in all these varied settings; instead, a broad range of techniques is needed.

Rather than supporting reductionism, public clooice theory can provide some useful additions to the judicial tool box. For example, as explained in Part I, formal models of legislation suggest a new formulation of legislative intent in terms of the set of stable voting outcomes. And, as explained in Part III, a formal model of the public choice variety suggests a way to enricl the search for legislative intent by incorporating a consideration of the "payoffs" of various statutory interpretations.

So far, public choice theory lias largely been the domain of specialists and a few outsiders, who have often used it to debunk the legislative process. Thus, it has probably fed a growing public and scholarly cynicism about legislation. In this Article, we hope to lhave demonstrated that public clooice models can provide some insights into the realities of legislation and statutory interpretation, without at the same time destroying respect for democratic institutions. 
HeinOnline -- 74 Va. L. Rev. 4701988 